\title{
ESCALA DIAGRAMÁTICA PARA AVALIAÇÃO DA MANCHA PRETA EM FOLHAS DE CITROS E EFEITO DA TEMPERATURA E DA DURAÇÃO DO MOLHAMENTO NA PRÉ-PENETRAÇÃO DE CONÍDIOS DE Guignardia citricarpa Kiely [Phyllosticta citricarpa (McAlp.) Van der Aa]
}

MARISSÔNIA DE ARAUJO NORONHA

Dissertação apresentada à Escola Superior de Agricultura "Luiz de Queiroz", Universidade de São Paulo, para obtenção do título de Mestre em Agronomia, Área de Concentração: Fitopatologia

P I R A C I C A B A

Estado de São Paulo - Brasil

Dezembro - 2002 


\title{
ESCALA DIAGRAMÁTICA PARA AVALIAÇÃO DA MANCHA PRETA EM FOLHAS DE CITROS E EFEITO DA TEMPERATURA E DA DURAÇÃO DO MOLHAMENTO NA PRÉ-PENETRAÇÃO DE CONÍDIOS DE Guignardia citricarpa Kiely [Phyllosticta citricarpa (McAlp.) van der Aa]
}

\section{MARISSÔNIA DE ARAUJO NORONHA}

Engenheiro Agrônomo

\author{
Orientadora: Profa. Dra. LILIAN AMORIM
}

\author{
Dissertação apresentada à Escola Superior de \\ Agricultura "Luiz de Queiroz", Universidade de São \\ Paulo, para obtenção do título de Mestre em \\ Agronomia, Área de Concentração: Fitopatologia
}

P I R A C I C A B A

Estado de São Paulo - Brasil

Dezembro - 2002 


\title{
Dados Internacionais de Catalogação na Publicação (CIP)
} DIVISÃO DE BIBLIOTECA E DOCUMENTAÇÃO - ESALQ/USP

\author{
Noronha, Marissônia de Ara ujo \\ Escala diagramática para avaliação da mancha preta em folhas de \\ citros e efeito da temperatura e da duração do molhamento na pré- \\ penetração de conídios de Guignardia c itric a rpa Kiely [Phyllostic ta \\ citric arpa (McAlp.) Van derAa] / Marissônia de Araujo Noronha. - - \\ Piracicaba, 2002. \\ 67 p. : il. \\ Dissertação (mestrado) - - Escola Superior de Agricultura Luiz de \\ Queiroz, 2002. \\ Bibliografia. \\ 1. Conídio 2. Efeito da temperatura 3. Efeito do molhamento 4. Fungo \\ fitopa togênico 5. Limão 6. Mancha-preta-dos-citros 7. Microscópia \\ eletrônic a de varredura I. Título
}

CDD 632.43

\section{'Permitida a cópia total ou parcial deste documento, desde que citada a fonte - $O$ autor'}


"O temor do Senhor é a instrução da sabedoria, e a humildade precede a honra". "O sábio de coração é chamado prudente, e a doçura dos lábios promove o ensino".

Prov. 15,$33 ; 16,21$

\section{À Deus OFEREÇO} e aos meus irmãos Murilo, Márcia, Marta, Marcela e Marciana. 


\section{AGRADECIMENTOS}

À Escola Superior de Agricultura "Luiz de Queiroz" - Universidade de São Paulo, Departamento de Entomologia, Fitopatologia e Zoologia Agrícola, Setor de Fitopatologia, pela oportunidade de realização deste curso.

À Profa. Dra. Lílian Amorim, pela orientação conduzida sempre com entusiasmo, atenção e paciência.

Ao Prof. Dr. Armando Bergamin Filho por ter tornado possível meu ingresso neste curso.

A Marcel Spósito, pela sugestão e auxílio neste trabalho.

À Coordenadoria de Aperfeiçoamento de Pessoal de Nível Superior (CAPES), pela concessão da bolsa de estudos.

Aos professores do Setor de Fitopatologia pelos ensinamentos ministrados nas disciplinas.

Ao Prof. Hiroshi Kimati, pelo carinho e atenção dispensados, sobretudo nos momentos difíceis.

Aos funcionários Marise, Marina, Jeferson e Pedro pelo carinho e auxílio.

Aos professores Sami J. Michereff e Rosa de Lima R. Mariano, por terem me iniciado na Fitopatologia e por estimularem o meu ingresso no Mestrado.

Ao Prof. Dr. Sérgio Resende, por ter acreditado que era possível tornar uma aluna de Escola Pública em uma candidata a pesquisadora em Fitopatologia.

A Fundação de Amparo a Ciência e Tecnologia do Estado de Pernambuco, órgão do qual eu sou fruto, na pessoa de Fátima Cabral, funcionária que acompanhou toda a minha trajetória com uma visão profissional e humana. 
Aos meus amigos Andréa, Conceição, Cristiano, Henrique, Jearbes, Jucélia, Neilza, Norma, Otacílio, Paulo, Ramalho, Ricardo, Simone e Viviane, sempre presentes em minha vida.

A Norinha, minha querida companheira com quem pude dividir todas as fases deste processo.

Aos amigos Ana Paula, Adriana, Alexandre, Antônio, Bianca, Cândido, Célia, Clecy, Daniel, Elisa, Elvis, Girlene, Júlio, Heloisa, Ivan, Kátia, Leila, Leonardo, Luís Fernando, Marília, Margarita, Nilceli, Paulo de Tarso, Paulo Albuquerque, Paulo Galhardi, Raquel, Rock, Santiago, Solange, Segundo, Silvia e Silvio, pelos cuidados comigo, pela presença nos momentos difíceis e alegres, pelo abraço dividido.

Aos amigos da feira, pessoas que fizeram dos sábados pela manhã um dia de esperança.

A todas as pessoas que com suas contribuições, tornaram possível a conclusão dessa dissertação, pois as conquistas nunca são individuais e sim coletivas. 


\section{SUMÁRIO}

Página

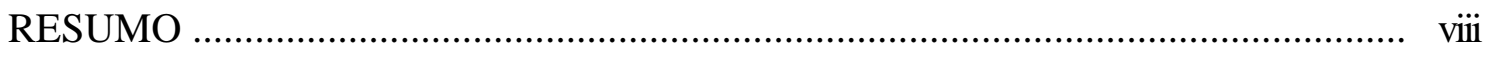

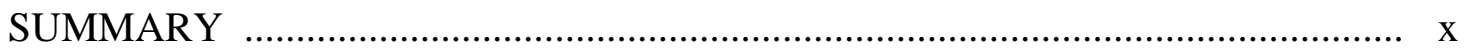

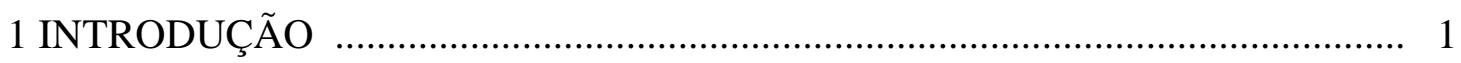

2 REVISÃO DE LITERATURA ………………………................................ 5

2.1. Importância da mancha preta dos citros …………………………………….... 5

2.1. Etiologia da mancha preta dos citros .................................................................

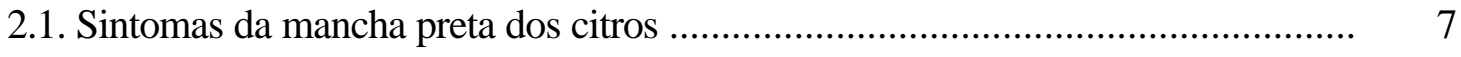

2.1.4 Epidemiologia da mancha preta dos citros ....................................................... 8

3 ESCALA DIAGRAMÁTICA PARA AVALIAÇÃO DA MANCHA PRETA EM FOLHAS DE CITROS .................................................................................. 13

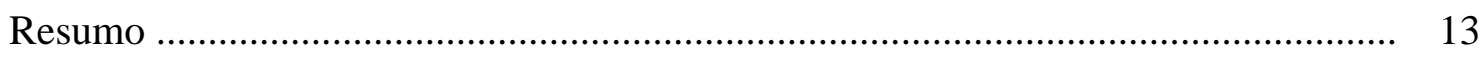

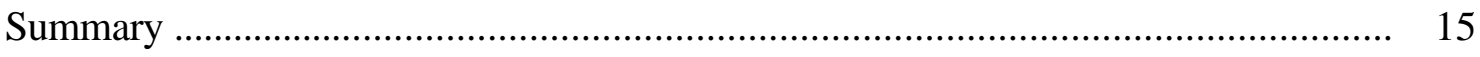

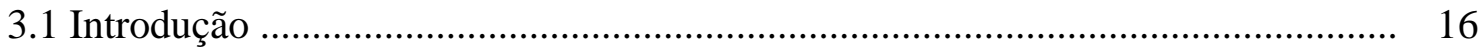

3.2 Marerial e Métodos ................................................................................... 19

3.2.1 Elaboração da escala diagramática ................................................................... 19

3.2.2 Validação da escala diagramática .................................................................... 20

3.2.3 Análise dos dados ............................................................................... 20

3.3 Resultados e Discussão ................................................................................. 21

3.3.1 Escala diagramática para quantificação da severidade da mancha preta em folhas de citros ............................................................................................ 21

3.3.2 Validação da escala diagramática ………………………………………...... 22

3.4 Conclusão .............................................................................................. 32 
4 EFEITO DA TEMPERATURA E DA DURAÇÃO DO MOLHAMENTO NA PRÉ-PENETRAÇÃO DE CONÍDIOS DE Guignardia citricarpa Kiely [Phyllosticta citricarpa (McAlp.) van der Aa] ................................................. 33

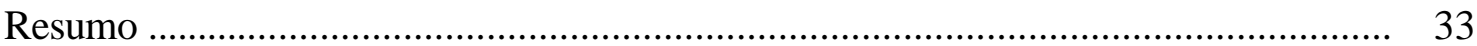

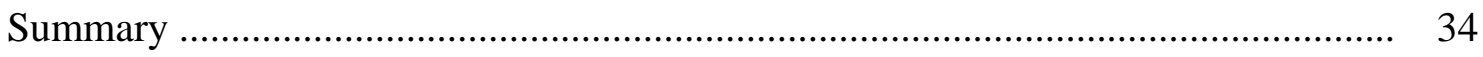

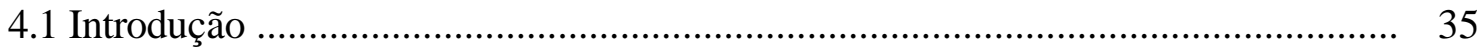

4.2 Material e Métodos ........................................................................................... 38

4.2.1 Instalação dos ensaios ...................................................................... 38

4.2.2 Obtenção e preparo do inóculo ................................................................... 38

4.2.3 Efeito da temperatura e da duração do molhamento na formação de apressórios de Guignardia citricarpa (Phyllosticta citricarpa), "in vitro" ................ 39

4.2.4 Análise dos dados ............................................................................. 40

4.2.5 Observação ao microscópio eletrônico de varredura da germinação e formação de apressórios de conídios de Guignardia citricarpa (Phyllosticta citricarpa) sobre folhas destacadas de limão 'Siciliano' submetidas a diferentes temperaturas e períodos de molhamento ..................................................................................... 41

4.3 Resultados e Discussão ............................................................................ 42

4.3.1 Efeito da temperatura e da duração do molhamento na formação de apressórios de Guignardia citricarpa (Phyllosticta citricarpa), "in vitro"................. 42

4.3.2 Observação ao microscópio eletrônico de varredura da germinação e formação de apressórios de conídios de Guignardia citricarpa (Phyllosticta citricarpa) sobre folhas destacadas de limão 'Siciliano' submetidas a diferentes temperaturas e períodos de molhamento .......................................................................... 51

4.4 Conclusões ........................................................................................ 54

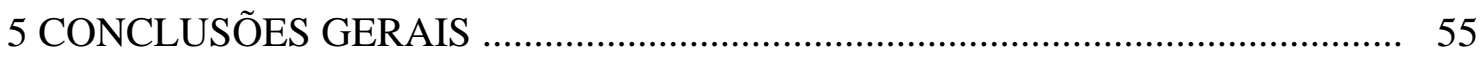

REFERÊNCIAS BIBLIOGRÁFICAS _........................................................ 56 


\title{
ESCALA DIAGRAMÁTICA PARA AVALIAÇÃO DA MANCHA PRETA EM FOLHAS DE CITROS E EFEITO DA TEMPERATURA E DA DURAÇÃO DO MOLHAMENTO NA PRÉ-PENETRAÇÃO DE CONÍDIOS DE Guignardia citricarpa Kiely [Phyllosticta citricarpa (McAlp.) Van der Aa]
}

\author{
Autora: MARISSÔNIA DE ARAUJO NORONHA \\ Orientadora: Profa. Dra. LILIAN AMORIM
}

\section{RESUMO}

A mancha preta dos citros causada pelo fungo Guignardia citricarpa Kiely [Phyllosticta citricarpa (McAlp.) Van der Aa], possui duas formas de infecção, conídios e ascósporos. Informações a respeito da importância dos conídios na epidemiologia da doença são escassas ou controversas. Visando uma maior compreensão sobre o patossistema citros- $G$. citricarpa ( $P$. citricarpa), os objetivos desta dissertação foram: elaborar e validar uma escala diagramática para avaliação da severidade da mancha preta em folhas de citros; verificar o efeito da temperatura e da duração do período de molhamento na formação de apressórios formados a partir de conídios; observar por meio de microscopia eletrônica de varredura a germinação de conídios e a formação de apressórios sobre folhas destacadas de limão 'Siciliano' submetidas a diferentes temperaturas e períodos de molhamento. A escala diagramática com níveis de severidade de $1 ; 3 ; 6 ; 12$; e $24 \%$ de área foliar lesionada foi validada por dois grupos de avaliadores, com e sem experiência na quantificação de doenças. Comparada com a 
avaliação sem escala, o uso da escala proporcionou melhor precisão e acurácia anto para avaliadores experientes como inexperientes, quando considerada a estimativa média dos mesmos. Na maioria dos casos, os desvios entre estimativas e severidade atual da doença foram mais evidentes para os níveis de severidade entre 5 e $15 \%$. A reprodutibilidade das avaliações resultou em valores de $R^{2}$ mais uniformes para a maioria dos avaliadores experientes. Diferenças consideráveis de precisão foram observadas entre avaliadores inexperientes. $\mathrm{O}$ efeito da temperatura $\left(10{ }^{\circ} \mathrm{C}-40{ }^{\circ} \mathrm{C}\right)$ e da duração do molhamento (4 - 48 h) na formação de apressórios formados a partir de conídios de G. citricarpa (P. citricarpa) foi avaliado sob condições "in vitro" e sobre a superfície de folhas de limão 'Siciliano'. A formação de apressórios ocorreu em todas as temperaturas a partir de 12 horas de molhamento, sendo os extremos de temperatura (10 ${ }^{\circ} \mathrm{C}$ e $40{ }^{\circ} \mathrm{C}$ ) menos favoráveis à formação de apressórios. A temperatura mínima para formação de apressórios, estimada pela função beta generalizada foi de $3{ }^{\circ} \mathrm{C}$ e a máxima de $48,4{ }^{\circ} \mathrm{C}$, ambas para 48 horas de molhamento. A formação de apressórios foi consideravelmente favorecida pela duração do período de molhamento, com o máximo de apressórios formados a 24 horas de molhamento, para a maioria das temperaturas. $\mathrm{O}$ período de molhamento constituído de 48 horas foi essencial para que os esporos submetidos a temperaturas de $10{ }^{\circ} \mathrm{C}$ e $40{ }^{\circ} \mathrm{C}$, formassem apressórios. A superfície de resposta obtida pela multiplicação das funções beta generalizada e monomolecular apresentou um ajuste satisfatório para os dados observados na estimativa da porcentagem relativa de apressórios formados $\left(R^{2}=0,75\right)$. As amostras observadas em microscopia eletrônica de varredura possibilitaram a aquisição de imagens de conídios e apressórios sobre a superfície de folhas de limão 'Siciliano' em todas as combinações de temperatura e molhamento avaliadas. 


\title{
DIAGRAMMATIC SCALE FOR ASSESSMENT OF CITRUS BLACK SPOT IN LEAVES AND EFFECT OF TEMPERATURE AND WETNESS DURATION IN THE PRE-PENETRATION CONIDIA OF Guignardia citricarpa Kiely [Phyllosticta citricarpa (McAlp.) Van der Aa]
}

\author{
Author: MARISSÔNIA DE ARAUJO NORONHA \\ Adviser: Profa. Dra. LILIAN AMORIM
}

\section{SUMMARY}

Citrus black spot caused by Guignardia citricarpa Kiely [Phyllosticta citricarpa (McAlp.) van der Aa] presents two infection forms, conidia and ascospores. Information regarding the importance of the conidia in the epidemiology of the disease is scarce and controversial. Seeking a better understanding on the pathosystem citrus-G. citricarpa ( $P$. citricarpa), the objectives of this dissertation were: elaborate and validate a diagrammatic scale for assessments of the citrus black spot; verify the effect of the temperature and of the wetness duration in the appressorium formation; observe through scanning electron microscopy the germination and formation of appressorium on outstanding lemon 'Siciliano' leaves submitted to different temperatures and wetness duration. The diagrammatic scale with severity levels of $1 ; 3 ; 6 ; 12$; and $24 \%$ of diseased leaf area was validated by two groups of raters, with experience and without experience in the quantification of diseases. The scale provided better precision and accuracy for both experienced and inexperienced raters, considering the estimates average of them. In 
the majority of cases, the bias between estimated and actual disease severity were more evident for disease severity levels between 5 and $15 \%$. The reproducibility of assessments resulted in $R^{2}$ with more uniforms values for the majority of the experienced raters, considerable differences of precision were observed among inexperienced raters. The effect of the temperature $\left(10{ }^{\circ} \mathrm{C}-40{ }^{\circ} \mathrm{C}\right)$ and of the wetness duration $(4-48 \mathrm{~h})$ in the germination of conidia and appressoria formation of $G$. citricarpa ( $P$. citricarpa), was assessed "in vitro" and on the surface of lemon ' Siciliano' leaves. The appressoria formation occurred in all the temperatures starting from 12 hours of wetness. The extreme temperatures $\left(10{ }^{\circ} \mathrm{C}\right.$ and $\left.40{ }^{\circ} \mathrm{C}\right)$ were less favorable to the apressorium formation. The minimum temperature for appressorium formation, estimated by generalized beta function was of $3{ }^{\circ} \mathrm{C}$ and the maximum of $48,4{ }^{\circ} \mathrm{C}$, both for 48 hours of wetness. The appressorium formation was favored considerably by the wetness duration period, with the maximum of apressoria formed at 24 hours of wetness, for majority of the temperatures. The wetness duration period constituted of 48 hours was essential so that the spores submitted to temperatures of $10{ }^{\circ} \mathrm{C}$ and $40{ }^{\circ} \mathrm{C}$, formed appressorium. The response surface obtained by the multiplication of the generalized beta and monomolecular functions provided a close fit to observed data in the estimate of the relative percentage of formed appressorium $\left(R^{2}=0,75\right)$. The samples observed in scanning electron microscopy made possible the acquisition of images of conidia and appressoria on the surface of lemon 'Siciliano' leaves in all the temperature combinations and wetness evaluated. 


\section{INTRODUÇÃO}

O Brasil, desde o início da década de 90, mantém-se como o maior produtor mundial de laranja, sendo responsável por $80 \%$ do comércio internacional de suco de laranja concentrado congelado. Para essa produção, avaliada em US\$ 900 milhões, gastam-se cerca de US\$ 410 milhões em insumos, movimentando-se aproximadamente US\$ 1,5 bilhões com a venda de produtos citrícolas, entre sucos e fruta fresca (FNP Consultoria \& Comércio, 2002). O segundo maior produtor são os Estados Unidos, seguido do México, China e Espanha. A Espanha e os Estados Unidos são os principais exportadores de frutas frescas, o que corresponde respectivamente a 38 e $18 \%$ das exportações mundiais (Boteon, 2002).

O Estado de São Paulo é responsável por cerca de 83,6 \% da produção brasileira de frutas cítricas, com uma produção média de 380 milhões de caixas no ano de 2000 (FNP Consultoria \& Comércio, 2001). O parque citrícola paulista, juntamente com o triângulo mineiro, conta com 198 milhões de árvores. A colheita de laranja faz-se durante todo o ano devido à composição das variedades, como 'Hamlin', 'Lima', 'Pera', 'Seleta', 'Bahia', 'Natal', 'Valência' e 'Folha Murcha'. Destas, algumas são próprias para a produção de suco, como 'Pera', que representa 38\% do total de árvores, seguida de 'Valência', 'Natal' e 'Hamlin', com respectivamente, 17, 25 e 7\% do total de árvores cujos frutos são destinados à produção de suco (Boteon, 2002).

Com a tecnificação da citricultura as plantas passaram as ser multiplicadas por enxertia, o que trouxe grandes vantagens em termos de precocidade e uniformidade aos pomares, porém ao mesmo tempo diminuiu a variabilidade, tornando a cultura um alvo constante de inúmeras pragas e doenças que, encontrando condições favoráveis ao seu desenvolvimento, são capazes de causar danos irreversíveis. Os custos fitossanitários, 
junto com os fertilizantes, ultrapassam $60 \%$ do custo da produção. A quantidade e a qualidade das frutas cítricas são freqüentemente ameaçadas devido aos danos deixados na planta, que dependendo da intensidade do ataque, podem torná-la improdutiva ou levar à sua erradicação.

No fim da década de 30 houveram problemas sem precedentes com o vírus da tristeza, o qual levou a uma erradicação de nove milhões de plantas cítricas em um parque, na época, de 11 milhões de plantas. Doenças importantes ainda mostram-se problemáticas como o cancro cítrico (Xanthomonas axonopodis), a clorose variegada dos citros (Xylella fastidiosa), a leprose (Citrus leprosis virus - CiLV), a gomose (Phytophthora spp.) e, em menor grau, outras doenças fúngicas tais como: podridão floral (Colletotrichum acutatum), verrugose (Elsinoe spp.), rubelose (Corticium salmonicolor) e melanose (Diaphorte citri). Entretanto, em 1992 foi constatada pela primeira vez em pomares paulistas a mancha preta dos citros (Guignardia citricarpa).

A mancha preta também denominada pinta preta, é uma doença responsável por elevados prejuízos na cultura dos citros, atingindo vários milhões de dólares em diferentes países da África, Ásia, Oceania e América do Sul. Sua importância econômica reside no fato de atingir as variedades cítricas mais importantes, depreciando os frutos comercialmente, podendo provocar a queda precoce dos frutos (Klotz, 1978). Devido ao longo período de suscetibilidade dos frutos, são necessárias várias pulverizações com fungicidas protetores ou sistêmicos, isoladamente ou combinados, associados ao óleo mineral ou vegetal, elevando assim, o custo de produção da cultura. No Brasil, o controle é baseado em informações geradas em outros países, especialmente da África do Sul, onde a doença também é de importância relevante (Goes, 2002).

Em São Paulo, a mancha preta já foi constatada em 44 municípios, podendo, entretanto, ter abrangência geográfica ainda maior (Fundecitrus, 1998). Devido à existência de condições ambientais altamente favoráveis à formação de inóculo, têm-se verificado severas epidemias em diferentes municípios do Estado de São Paulo (Goes et al., 2000). Dada a possibilidade de disseminação do patógeno através de mudas, por não exibir sintomas aparentes, é provável que nos próximos anos a doença venha apresentar 
uma distribuição mais ampla, não só no Estado de São Paulo como em outros Estados (Goes, 2002).

As variedades comerciais são suscetíveis, principalmente frutos de limoeiros, laranjeiras doces, pomeleiros e tangerineiras (McOnie, 1964a). Os limoeiros mostram-se mais suscetíveis. Em laranjeiras, grandes perdas podem ocorrer especialmente em variedades de maturação tardia, como a 'Valência'. Frutos com mancha preta são depreciados para o mercado de frutas frescas, porém podem ser usados para o processamento de suco (Kotzé, 1988; Goes 2002).

Para o mercado interno, assim como, para a exportação de frutas frescas, a aparência é de suma importância. A mancha preta já encontra-se na lista de doenças quarentenárias de mercados potenciais. Neste sentido a presença desta doença em pomares brasileiros tem sido considerada uma barreira fitossanitária, limitando as fronteiras de exportação de frutas cítricas, principalmente para a União Européia.

Embora o significado econômico desta doença já tenha sido reconhecido por um longo período, informações detalhadas a respeito de sua epidemiologia têm sido limitadas e até certo ponto controversas (Kotzé, 1996). Fatores como temperatura e precipitação, que variam nas distintas regiões citrícolas, influenciam tanto na sobrevivência, na esporulação e na dispersão do patógeno, como na fisiologia do hospedeiro (época de florescimento, taxa de crescimento dos frutos) que somados determinam o início e a duração do período de infecção (Alcoba et al., 2000). O conhecimento dos efeitos da interação entre os fatores de clima e as diferentes fases do ciclo da doença pode permitir a previsão com maior efetividade não somente da ocorrência das epidemias, mas também da taxa de aumento das doenças.

Estudos com a mancha preta dos citros em condições controladas são difíceis, pois os frutos só se formam em plantas com pelo menos quatro anos de idade. A manutenção dessas plantas em vasos é cara, trabalhosa e exige enorme espaço, não disponível na maioria das câmaras de crescimento. Considerando que folhas de citros são colonizadas pelo patógeno e que apenas algumas espécies de citros, como os limoeiros, manifestam os sintomas da doença, uma alternativa para estudos 
epidemiológicos, sob condições controladas, é a utilização de mudas jovens de limoeiros. Para tanto, a quantificação da doença deve ser efetuada por métodos que proporcionem a aquisição de dados confiáveis. A severidade é um parâmetro quantificável e o mais apropriado para medir doenças foliares. Escalas diagramáticas, atualmente, têm se constituído numa importante ferramenta na avaliação da severidade (Bergamin Filho \& Amorim, 1996), por proporcionarem medidas mais acuradas e precisas devido ao treinamento dos avaliadores.

Os objetivos desta dissertação foram:

Elaborar e validar uma escala diagramática para avaliação da mancha preta em folhas de citros, adotando os critérios que respeitam os limites da acuidade visual humana e normas para a elaboração de escalas diagramáticas.

Verificar o efeito da temperatura e da duração do período de molhamento na formação de apressórios de conídios de Guignardia citricarpa (Phyllosticta citricarpa), sob condições controladas;

Observar, por meio de técnicas de microscopia eletrônica de varredura, o efeito da temperatura e da duração do período de molhamento m germinação e formação de apressórios de G. citricarpa ( $P$. citricarpa), sobre a superfície de folhas de limão 'Siciliano'. 


\section{REVISÃO DE LITERATURA}

\subsection{Importância da mancha preta dos citros}

A mancha preta dos citros causada pelo fungo Guignardia citricarpa Kiely [Phyllosticta citricarpa (McAlp.) Van der Aa.] foi descrita pela primeira vez, em 1895, na Austrália, em áreas próximas a Sidney, causando perdas significativas em frutos de laranjeira 'Valência' (Kiely, 1948). Em 1925, a doença foi identificada na África do Sul, na região litorânea e úmida da província de Natal (Doidge, 1929), tornando-se rapidamente o principal problema fitossanitário daquele país, fato que perdura até hoje (Schutte et al., 1997). Nos anos seguintes a doença foi relatada em outros países, incluindo China, Filipinas, Indonésia, Taiwan e Japão, na Ásia; Swazilândia, Zimbabwe e Moçambique, na África; Argentina, Peru e Brasil, na América do Sul (Kotzé, 1988; Feichtenberger, 1996; Feichtenberger et al., 1997).

A mancha preta foi descrita no Brasil, em 1980 (Robbs et al., 1980), afetando pomares comerciais em São Gonçalo e Itaboraí, no Estado do Rio de Janeiro. A partir desses municípios, o patógeno disseminou-se rapidamente para outros municípios da Baixada Costeira Fluminense (Robbs, 1990; Robbs \& Bittencourt, 1995). A doença foi identificada em 1986 no Rio Grande do Sul, no Vale do Caí, principal região produtora daquele estado (Feichtenberger, 1996).

No Estado de São Paulo, a mancha preta foi relatada em 1992, em limoeiros verdadeiros e laranjeiras doces de maturação tardia, nos municípios de Conchal e Engenheiro Coelho (Goes \& Feichtenberger, 1993). A disseminação da doença na região deu-se com rapidez, possibilitando, assim, a distribuição do patógeno de forma endêmica em toda a região citrícola de Limeira, municípios de Araras, Rio Claro, Mogi 
Guaçu, Aguaí, Pirassununga, Santa Cruz das Palmeiras e Casa Branca (Feichtenberger, 1996; Goes, 1998).

A mancha preta dos citros é de importância econômica por afetar a produção, o aspecto dos frutos e a comercialização de frutas frescas. Esta doença quarentenária restringe a comercialização de material de propagação, mudas e frutos. Estes fatores causam perdas de divisas para o Brasil, em razão das restrições fitossanitárias impostas por países como os Estados Unidos e a Comunidade Européia (Aguilar-Vildoso, 2002).

\subsection{Etiologia da mancha preta dos citros}

A mancha preta dos citros é causada pelo fungo Guignardia citricarpa Kiely, cuja forma anamórfica corresponde a Phyllosticta citricarpa (McAlp.) van der Aa (sin.= Phyllosticta citricarpa (McAlp.) Petrak.). A forma imperfeita do fungo foi inicialmente descrita como Phoma citricarpa Mc Alpine. Pseudotécios são encontrados apenas em folhas de citros caídas em decomposição no solo. Os pseudotécios são isolados ou agregados, globosos, imersos, de coloração castanho-escuro a preta, com 95-125 $\mu \mathrm{m}$ de diâmetro, ostíolo não papilado, circular, com 10-17,5 $\mu \mathrm{m}$ de diâmetro e pseudoparáfises ausentes. Os ascos são cilíndrico-clavados (40-64 x 12-15 $\mu \mathrm{m})$, de parede bitunicada, contendo oito ascósporos unicelulares, hialinos, multigutulados, cilíndricos com o centro dilatado (12,5-16 x 4,5-6,5 $\mu \mathrm{m})$ e apêndices hialinos nas duas extremidades obtusas (Baldassari et al., 2001b).

A fase assexual, representada por $P$. citricarpa, produz picnídios em lesões nos ramos, frutos e folhas e em folhas em decomposição. Os picnídios são solitários, às vezes agregados, globosos, com 115-190 $\mu \mathrm{m}$ de diâmetro, coloração marrom escura para preta, ostíolo levemente papilado, circular e com 12-14,5 $\mu \mathrm{m}$ de diâmetro. Os conídios possuem formato obovóide para elíptico, hialinos, unicelulares, multigutulados, com um apêndice hialino em uma das extremidades, base truncada e medem 810,5 x 5,5-7 $\mu \mathrm{m}$. O conidióforo é cilíndrico e alongado com $9 \mu \mathrm{m}$ de comprimento (Baldassari et al., 2001b; Sutton \& Waterson, 1966). 
Dos isolamentos realizados de lesões de frutos e folhas obtém-se colônias negras de bordos lobulados, de aspecto granuloso. Devido ao desenvolvimento de picnídios nestes cultivos, é comum que se desenvolva simultaneamente o estado espermácio deste fungo que corresponde ao gênero Leptodothiorella. Neste estado são produzidas espermácias baciliformes, que são células especializadas, masculinas, unicelulares e participam da reprodução sexual, da qual origina-se os ascomas ou pseudotécios do estado teleomórfico. Considera-se um estado intermediário entre o anamórfico e o teleomórfico (Alcoba et al., 2000).

\subsection{Sintomatologia da mancha preta dos citros}

Os órgãos afetados pela mancha preta dos citros podem ser em ordem de freqüência: frutos, folhas, pedúnculos, pecíolos, ramos verdes e espinhos. Uma das principais características desta doença é que folhas e frutos podem estar infectados sem apresentarem os sintomas típicos da doença (Aguilar-Vildoso, 2002). As lesões produzidas restringem-se ao flavedo, prejudicando a comercialização de frutas frescas (Goes, 1998).

Os distintos tipos de sintomas correspondem a um progresso da enfermidade no tempo. Por isso, nos frutos de todas as espécies cítricas pode-se observar lesões de um só tipo ou uma mescla delas, como consequiência da evolução da doença que acompanha a intensificação da cor amarela ou alaranjada da fruta segundo a espécie, já que se trata de frutos com maturação progressiva (Alcoba et al., 2000). As condições ambientais após o estabelecimento de infecções latentes e o tipo de esporo responsável pela infecção determinam o desenvolvimento do tipo de lesão (Aguilar-Vildoso, 2002; McOnie, 1964c).

Atualmente, os sintomas vêm sendo classificados em cinco tipos. A mancha dura é o sintoma mais típico e comum da doença e geralmente surge quando os frutos iniciam a fase de mudança de cor da casca, levando a maturação externa. O sintoma de mancha sardenta ocorre em frutos maduros e em pós-colheita. A mancha virulenta é resultado da fusão dos diferentes tipos de sintomas. O sintoma de falsa melanose assemelha-se ao da 
melanose dos citros causada pelo fungo Diaporthe citri. Em frutos verdes ocorre o sintoma de mancha trincada, podendo atingir desde pequenas áreas até quase a totalidade do fruto (Goes, 1998).

Um novo sintoma associado à doença vem sendo observado no Estado de São Paulo desde 1996, sendo mais freqüente na safra 2000/01 nas regiões de Conchal e Mogi Guaçu, em laranjeiras doces. Ele ocorre em frutos verdes na forma de lesões superficiais, restringindo-se à epiderme da casca dos frutos, de coloração marrom a marrom escura, aspecto encharcado, mas quais não há corpos de frutificação. Ao envelhecer elas podem apresentar rachaduras na sua superfície. Os sintomas ocorrem principalmente de janeiro a março. A distribuição das lesões nos frutos sugere que elas sejam decorrentes de infecções produzidas por conídios, em épocas de chuvas freqüentes, porém de baixa intensidade (Schinor et al., 2001a).

Em folhas de limoeiros é comum observar sintomas parecidos com os sintomas de mancha dura dos frutos; são lesões circulares de 1 a $2 \mathrm{~mm}$ de diâmetro, de bordo pardo escuro com tonalidades vermelhas, centro claro, onde se desenvolvem os picnídios de $G$. citricarpa ( $P$. citricarpa). Outra espécie cítrica que também pode apresentar sintomas nas folhas é a tangerineira, com lesões semelhantes às de limoeiro, porém em menor diâmetro. Em pomeleiro os sintomas em folhas são raros, contudo, em lotes muito afetados podem chegar a manifestar sintomas (Alcoba et al., 2000).

\subsection{Epidemiologia da mancha preta dos citros}

A epidemiologia da mancha preta é influenciada pelos seguintes fatores: inóculo disponível; condições climáticas requeridas para ocorrer à infecção; ciclo de crescimento das árvores de citros e idade do fruto em relação à suscetibilidade para infecção e eventual desenvolvimento dos sintomas (Kotzé, 1988).

A mancha preta dos citros apresenta os ciclos primário e secundário bem distintos. O primeiro, representa a fase sexual de Guignardia citricarpa, cujas estruturas infectivas são os ascósporos, responsáveis pela introdução do patógeno na área e início das epidemias a cada ciclo da cultura. O ciclo secundário é caracterizado pela fase 
assexual do fungo (Phyllosticta citricarpa), onde os conídios são responsáveis pelo incremento da doença na planta e ao seu redor (Aguilar-Vildoso, 2002; Kiely, 1948).

Os pseudotécios, estruturas responsáveis pela formação dos ascos e ascósporos, só podem ser encontrados completos e maduros apenas em folhas em estado de decomposição intermediário, onde estas mostram-se secas e não quebradiças, com consistência semelhante a de um papel. O desenvolvimento de pseudotécios nas folhas caídas ao solo depende das infecções que tenham ocorrido durante o período de suscetibilidade no ciclo de vida das mesmas. (Alcoba et al., 2000). Pseudotécios maduros podem ocorrer em qualquer tempo durante todo o ano em pomares de citros, porém, formam-se apenas em folhas em decomposição, de 50 a 180 dias após sua queda (Kotzé, 1996). A produção de ascósporos é dependente do momento da desfolha, da velocidade de decomposição das folhas, que é influenciada pela alternância entre períodos secos e úmidos, estando assim, diretamente relacionada com as temperaturas e precipitações prevalecentes (Alcoba et al., 2000), situação freqüente em áreas irrigadas ou no caso de São Paulo, durante a estação chuvosa do ano. Os ascósporos liberados são ejetados em uma altura de $1 \mathrm{~cm}$, carregados por correntes de ar e disseminados a longas distâncias (Kotzé, 1963). A produção de esporos sexuais no ciclo primário é de suma importância para a sobrevivência do fungo, devido à sua maior viabilidade e tolerância ao ressecamento. Folhas de citros caem durante todo o ano em alguns países e sazonalmente em outros e isto afeta a disponibilidade do inóculo (Kotzé, 1996). Em São Paulo, a queda de folhas é ininterrupta, embora no inverno a desfolha seja mais intensa (Aguilar-Vildoso, 2002).

Os conídios são produzidos em picnídios formados principalmente em lesões de frutos maduros, bem como em folhas velhas caídas e, ocasionalmente, em folhas novas, hastes de frutos e ramos mortos (Smith, 1996). Os conídios são as principais estruturas responsáveis pela disseminação do fungo à curta distância, e emergem de um ostíolo, envolvidos por uma substância muscilaginosa que é facilmente solubilizada e transportada pela água das chuvas, orvalho ou irrigação, atingindo a superfície de órgãos suscetíveis, podendo dessa forma iniciar novas infecções (Kiely, 1948; Kotzé, 1981; 1988; Robbs et al., 1985). Hoto et al. (2001), acompanhando o processo ontogênico de 
picnídios observaram que após 21 dias os picnídios estavam vazios, indicando que a completa liberação de conídios ocorre antes deste período.

O período crítico para a infecção ocorre após a queda das pétalas e estende-se até quatro a cinco meses de desenvolvimento dos frutos, segundo relatos da África do Sul (Kotzé, 1988). No Brasil, este período parece ser maior. De acordo com Baldassari (2001a), a suscetibilidade das laranjas 'Natal' e 'Valência' à infecção é de pelo menos seis meses. Os esporos de ambas as formas germinam na superfície de órgãos suscetíveis e produzem tubo germinativo e apressório do qual se origina um delgado "peg" de penetração que penetra a cutícula, dando origem a uma pequena massa de micélio entre a cutícula e a epiderme do órgão infectado. Nessa forma de micélio subcuticular quiescente o fungo pode permanecer dormente por até doze meses. O período de dormência ou de infecção latente pode ser interrompido quando o fruto atingir seu tamanho final e iniciar a maturação ou quando a folha, já caída, começar a se decompor. O patógeno, então, cresce a partir do micélio subcuticular e coloniza tecidos mais internos, produzindo os sintomas típicos da doença (McOnie, 1967; Kotzé, 1988). Fatores como radiações solares intensas e altas temperaturas são fundamentais na manifestação da mancha preta (Kotzé, 1981; 1996).

De acordo com vários autores, os ascósporos representam a principal fonte de inóculo (Kiely, 1948; 1949; McOnie, 1964a; 1964b; 1965; 1967; Kotzé, 1981; 1988; 1996; Schutte et al., 1997, Smith, 1996). Esta afirmação se justifica pelo fato de na África do Sul e Austrália os frutos de citros iniciarem a maturação durante o outono e inverno, sendo frutos com lesões e picnídios normalmente removidos das árvores um mês antes do estabelecimento da mva frutificação. Nestes países, esta doença mostra-se monocíclica, admitindo apenas o ciclo primário (infecção a partir de ascósporos), desconsiderando o possível papel do ciclo secundário (diversos ciclos assexuais recorrentes) no desenvolvimento da epidemia. Esse comportamento epidemiológico proposto para a mancha preta nesses países justifica-se, em parte, pela ocorrência de florescimento e frutificação uniformes (típicos de pomares irrigados), condição esta que permite a colheita de uma determinada safra antes que se inicie o florescimento e a frutificação da safra seguinte (Kotzé, 1981).Conídios não possuem mecanismo especial 
de liberação dentro da atmosfera, ocorrendo em folhas em decomposição no solo, podendo alcançar frutos suscetíveis apenas por respingos de chuva. Contudo, conídios podem ser uma significante fonte de inóculo quando frutos temporões ou frutos com lesões permanecem pendurados em árvores de uma estação para outra após a floração e estabelecimento do fruto; conídios formados em picnídios presentes nesses frutos podem ser disseminados para frutos jovens (Kotzé, 1996).

Em folhas em decomposição no solo, picnídios normalmente maduros liberam conídios por várias semanas antes da maturação dos primeiros pseudotécios nas mesmas folhas. A correlação entre descarga de ascósporos e o início da infecção, indicam, portanto, que picnídios em folhas em decomposição não possuem um papel importante. Embora pseudotécios sejam considerados em muitos trabalhos como a mais importante fonte de inóculo, a possibilidade de infecções significativas por conídios sob algumas circunstâncias não pode ser desconsiderada (McOnie, 1964a), pois, a importância relativa destas duas formas de inóculo tem sido muitas vezes mal interpretada (Kotzé, 1996).

A forma conidial pode ser importante na epidemiologia da mancha preta somente quando, na mesma planta, coabitam frutos maduros já infecciosos e frutos jovens suscetíveis (ou seja, frutos de até seis meses de idade a contar da queda das pétalas). Essa situação é incomum tanto na África do Sul (Kotzé, 1988; 1996) quanto na Austrália (Kiely, 1948; 1949), mas ocorre com frequiência no Brasil, fato que torna único o patossistema nas nossas condições (Feichtenberger, 1996; Feichtenberger et al., 1997; Goes, 1998). Em trabalhos iniciais realizados no Brasil sobre a distribuição espacial da mancha preta dos citros em pomar de laranjeira 'Natal', Spósito et al. (2001), constataram que no início da evolução da doença no pomar, as plantas sintomáticas possuem um padrão de distribuição aregado e que a ocorrência da doença é verificada num raio de 30 metros a partir de uma planta doente, sugerindo, assim, o envolvimento adicional de conídios aos ascósporos na dispersão da doença.

Schinor (2001b), avaliando a quantificação e a distribuição da incidência e da severidade dos frutos com sintomas da manha preta em áreas de citros na safra de 1999 para 2000, obteve os menores valores tanto para a incidência quanto para a severidade 
da doença nas avaliações acima de 2 metros de altura. A presença maior de sintomas em frutos na parte baixa da planta sugere que a disseminação ocorreu por água, assim como ocorre para a melanose dos citros (Diaporthe citri), portanto a participação de conídios de G. citricarpa (P. citricarpa) no incremento da doença (Kotzé, 1963).

A despeito da crescente importância da mancha preta nos pomares brasileiros, pouco se sabe sobre sua epidemiologia nas nossas condições. No Brasil, o papel dos conídios deve ser tão (ou mais) importante quanto o papel dos ascósporos, em virtude da comum ocorrência de frutos maduros infecciosos (por meio de conídios de Phyllosticta citricarpa) e frutos jovens suscetíveis na mesma árvore (ou em árvores próximas), principalmente naquelas variedades com vários surtos de florescimento, ou mesmo em qualquer variedade, quando condições climáticas particulares contribuem para a ocorrência de vários surtos de florescimento nas plantas (Feichtenberger, 1996).

A influência da temperatura e do tempo de incubação na germinação de ascósporos de G. citricarpa foi verificada em trabalhos realizados por Timossi (2000), onde as maiores médias de germinação ocorreram nas temperaturas de 21 e $24{ }^{\circ} \mathrm{C}$, após 18 horas de incubação, sendo os extremos de temperatura de 15 e $33{ }^{\circ} \mathrm{C}$ menos favoráveis a germinação de ascósporos. Kiely (1948) relatou que ascósporos requerem mais que 24 horas para germinar e aproximadamente 48 horas para desenvolver apressório. McOnie (1967), avaliando a germinação e formação de apressório de ascósporos de G. citricarpa, verificou que a taxa de formação de apressório foi extremamente variável, embora o tempo de formação de apressório tenha sido consideravelmente mais rápido que o relatado por Kiely (1948). Segundo McOnie (1967), até 11 horas não havia ocorrido formação de apressório, enquanto que após 18 horas, $48 \%$ dos ascósporos tinham desenvolvido apressório.

Glienke de Blanco (1999) observou uma baixa taxa de germinação de conídios de G. citricarpa (P. citricarpa) sob condições "in vitro", a autora sugere que esta baixa germinação deve-se a ausência de uma superfície adesiva. A germinação de conídios e formação de apressório foi observada na superfície de folhas de citros inoculadas e submetidas à incubação por 72 horas a $28^{\circ} \mathrm{C}$ de temperatura. 


\section{ESCAla diagramática PARA AVAliaÇÃo da MANCHA PRETA EM FOLHAS DE CITROS}

Resumo

Uma escala diagramática foi desenvolvida para avaliação de sintomas de mancha preta dos citros em folhas, causados pelo fungo Guignardia citricarpa (Phyllosticta citricarpa), considerando os limites de severidade mínima e máxima da doença observados no campo e os níveis intermediários seguiram incrementos logarítmicos, representando: $1 ; 3 ; 6 ; 12$; e $24 \%$ da área foliar lesionada. A validação da escala consistiu em duas fases: na primeira fase um total de 14 avaliadores distribuídos em dois grupos diferentes, com e sem experiência na quantificação de doenças de plantas avaliaram 27 folhas com diferentes níveis de severidade, sem o uso da escala diagramática. Na segunda fase, os mesmos avaliadores estimaram a severidade da doença em 30 folhas com a ajuda da escala. Regressões lineares entre severidades real e estimada foram calculadas. Em avaliações sem o uso da escala diagramática os coeficientes de determinação variaram entre 0,51 a 0,90 e 0,31 a 0,83, para avaliadores experientes e inexperientes, respectivamente. Os coeficientes angulares diferiram da unidade $(\mathrm{p}<0,05)$ para a maioria dos avaliadores. Com o auxílio da escala, dentre todos os avaliadores, oito melhoraram sua precisão, enquanto seis foram menos precisos. Os erros absolutos sem o auxílio da escala para avaliadores experientes e inexperientes variam de $-5,31$ a 36,14 e $-5,06$ a 39,14, respectivamente. Com o uso da escala os erros absolutos foram de $-8,70$ a 17,11 e $-10,7$ a 10,66 para avaliadores experientes e inexperientes, respectivamente. Para ambos os grupos de avaliadores, na maioria dos casos, os desvios foram mais evidentes para os níveis de severidade entre 5 e 15\%. A reprodutibilidade das 
avaliações, calculada pelo coeficiente de determinação das regressões lineares entre combinações da estimativa do melhor avaliador com os demais, resultou em valores de $R^{2}$ mais uniformes para a maioria dos avaliadores experientes, e coeficientes angulares que não diferiram significativamente da unidade $(p<0,05)$ para três das seis combinações. Avaliadores inexperientes apresentaram diferenças consideráveis de precisão entre si. A escala proporcionou melhor precisão e acurácia tanto para avaliadores experientes como inexperientes, quando considerada a média dos mesmos. A escala mostrou-se adequada para avaliações da severidade da mancha preta em folhas de citros. 


\section{Diagrammatic scale for evaluation of the black spot in citrus leaves}

\section{Summary}

A diagrammatic scale was developed for assessments of symptoms of black spot citrus leaves, caused by fungi Guignardia citricarpa (Phyllosticta citricarpa), considering the lowest and highest limits of severity observed in the field. Intermediate levels followed logarithmic increments, representing: 1; 3; 6; 12 and $24 \%$ of diseased leaf area. The validation of the scale consisted in two stages: in the first stage a total of 14 raters distributed in two different groups (one with experience and the other without experience in quantification of plants diseases) evaluated 27 leaves with different levels of disease severity, without the use of the diagrammatic scale. In the second stage, the same raters estimated the severity of the disease in 30 leaves with the scale. Regression lines between actual and estimated severity were calculated. In evaluations without the use of the diagrammatic scale the determination coefficients varied between 0.51 to 0.90 and 0.31 to 0.83 , for experienced and inexperienced raters, respectively. The angular coefficients differed of the unit $(\mathrm{p}<0.05)$ the majority of the raters. When the scale was used, eight raters improved their precision, while six raters were less precise. The absolute errors without using of the scale, for experienced and inexperienced raters, varied from -5.31 to 36.14 and -5.06 to 39.14 , respectively. When the scale was used the absolute errors were from -8.70 to 17.11 and -10.7 to 10.66 for experienced and inexperienced raters, respectively. For both groups of raters, in the majority of cases, the bias were more evident for disease severity levels between 5 and $15 \%$. The reproducibility of assessments was estimated by the coefficient of determination of regression lines between combinations of the best rater with the others. It resulted in $R^{2}$ with more uniforms values for the majority of the experienced raters, and angular coefficients that did not differ significantly of the unit $(\mathrm{p}<0,05)$ for three of the six combinations. Inexperienced raters presented considerable differences of precision among themselves. The scale provided better precision and accuracy both for experienced and inexperienced raters, considering the average obtained for them. This diagrammatic scale showed to be appropriate for assessments of severity of black spot in citrus leaves. 


\subsection{Introdução}

A mancha preta dos citros, também denominada pinta preta, tem como agente causal o fungo Guignardia citricarpa Kiely [Phyllosticta citricarpa (McAlp.) van der Aa.]. Sua importância econômica reside no fato de atingir as variedades cítricas mais importantes, depreciando os frutos comercialmente, reduzindo a produtividade e provocando a queda precoce dos frutos. Devido ao longo período de suscetibilidade dos frutos, várias pulverizações com fungicidas são necessárias para o seu controle, elevando o custo de produção da cultura (Goes et al., 2000).

Todas as variedades cítricas comerciais são suscetíveis, principalmente frutos de limoeiros, laranjeiras doces, pomeleiros e tangerineiras (McOnie, 1964a). Os limoeiros mostram-se mais suscetíveis. Em laranjeiras, perdas consideráveis podem ocorrer especialmente em variedades de maturação tardia. Os sintomas podem surgir em pomares nos frutos ainda verdes, durante os estádios avançados de desenvolvimento do fruto ou após a colheita (Kotzé, 1988).

A mancha preta é uma doença de expressão quase que exclusiva de frutos em laranjas doces. Todavia, a presença de sintomas pode ocasionalmente ser verificada em folhas, hastes de frutos, ramos mortos e no pedúnculo dos frutos (Smith, 1996; Kotzé, 1981). Dentre estes tecidos os sintomas são encontrados com maior frequiência em folhas de limoeiros e de tangerineiras (Goes, 2000). Folhas sintomáticas são caracterizadas pela presença de manchas necróticas pequenas, ligeiramente deprimidas, circulares, com um bordo marrom-escuro bem definido e centro acinzentado contendo as frutificações do fungo (Goes, 1998; Kotzé, 1988). Em folhas velhas caídas ou em decomposição no solo, numerosos picnídios são formados, e normalmente, quando maduros os conídios são liberados em uma massa mucilaginosa por várias semanas. A produção de conídios em folhas em decomposição antecede a maturação de pseudotécios e a liberação de ascósporos. Folhas de citros caem durante todo ano em alguns países e sazonalmente em outros e isto afeta a disponibilidade do inóculo (Kotzé, 1996). Em São Paulo a queda de folhas é ininterrupta, embora no inverno a desfolha seja mais intensa (AguilarVildoso, 2002). 
A quantificação da doença é considerada uma das fases mais importantes em um programa de manejo de doenças de plantas, motivo pelo qual o desenvolvimento e/ou a comparação de métodos de quantificação podem prevenir sérios erros na aquisição de dados que são necessários tanto para o estudo de medidas de controle, como para a construção de curvas de progresso da doença e estimativas dos danos por ela provocados (Bergamin Filho \& Amorim, 1996).

Várias técnicas modernas podem ser usadas para avaliar a severidade da doença com precisão: imagens de vídeo, fotografia infravermelha, termógrafo infravermelho, reflectância espectral de copa e imagem de ressonância magnética nuclear (Nilsson, 1995). Tais técnicas requerem equipamentos sofisticados e caros. Devido a essas inconveniências, a severidade de doenças foliares é avaliada, geralmente, visualmente, gerando assim, estimativas subjetivas da severidade. Neste caso, escalas diagramáticas se tornaram a principal ferramenta de avaliação, pois contribuem para reduzir a subjetividade de cada avaliação (Godoy et al., 1997).

A estimativa da severidade consiste em um método direto de avaliação de doenças, sobretudo doenças foliares, onde a porcentagem da área de tecido foliar coberto por sintomas retrata melhor a intensidade da doença que a incidência (porcentagem de plantas doentes ou partes de plantas em uma amostra ou população) (Amorim, 1995). Embora a estimativa da severidade da doença seja um método subjetivo de avaliação de doença, esta variável é a que melhor se relaciona ao dano causado pelos patógenos. Dentre as várias estratégias propostas para facilitar a avaliação da severidade de doenças, diversas escalas diagramáticas têm sido adotadas como padrões de comparação, representativos da área foliar lesionada (Leite \& Amorim, 2002; Díaz et al., 2001; Michereff et al.,1998; Amorim et al., 1993 ).

Escalas diagramáticas são representações ilustradas de uma série de plantas ou partes de plantas com sintomas em diferentes níveis de severidade (Bergamin Filho \& Amorim, 1996). Sua elaboração deve levar em consideração os seguintes aspectos: o limite superior da escala deve corresponder à quantidade máxima de doença observada no campo; a determinação da quantidade real de doença no campo e sua representação na escala devem ter alta precisão; as subdivisões da escala devem respeitar as limitações da acuidade visual humana; a vista humana lê tecido doente para níveis de severidade abaixo de 50\% (Horsfall \& Cowling, 1978; James, 1971). 
Escalas diagramáticas devem ser de fácil uso, aplicáveis a uma ampla série de diferentes condições, e devem produzir resultados reprodutíveis, além de apresentar níveis suficientes que representem todos os estádios de desenvolvimento da doença (Berger, 1980). Além das recomendações técnicas para o desenvolvimento de escalas diagramáticas, o sucesso na sua utilização depende também da experiência e percepção visual de cada individuo (Godoy et al., 1997).

Devido à estimativa direta da área foliar lesionada ser subjetiva, variações quanto a precisão e acurácia, normalmente são comuns, sendo necessário proceder a análises estatísticas de regressão linear simples para mensurá-las (Godoy et al., 1997). Acurácia descreve o quanto a média de uma estimativa é próxima do valor real da quantidade de doença avaliada. Precisão descreve a repetibilidade ou variações associadas com uma estimativa, desconsiderando a média do valor (Martin, 1971, citado por Parker et al., 1995). ${ }^{1}$

Acurácia e precisão na avaliação de doenças são requeridas para avaliar corretamente estratégias de manejo da doença, para quantificar e modelar progresso da doença no tempo e no espaço, para predizer quantidades futuras de doenças, e elucidar a relação entre injúria e dano (Madden \& Nutter, 1995; Nutter et al., 1991).

A despeito da crescente importância da mancha preta dos citros nos pomares brasileiros, pouco sabe-se sobre sua epidemiologia nas nossas condições. A elaboração e validação de uma escala diagramática para avaliação da severidade da mancha preta em folhas de limoeiro, constitui-se em uma ferramenta necessária em estudos que visam uma melhor compreensão do patossistema citros-G. citricarpa ( $P$. citricarpa). Estudos sobre o efeito de variáveis do ambiente no progresso de doenças são usualmente realizados durante $\mathrm{o}$ primeiro ciclo da doença sob condições controladas com mudas de plantas cítricas. Nesses estudos, o progresso da doença é avaliado nas folhas e, a avaliação precisa da severidade é essencial para garantir a confiabilidade dos resultados.

\footnotetext{
${ }^{1}$ MARTIN, B.R. Statistes for Physicists .London:Academic Press. 1971.
} 
O objetivo deste trabalho foi desenvolver e validar uma escala diagramática para avaliação da severidade da mancha preta em folhas limão 'Siciliano', sendo esta uma ferramenta necessária em estudos que visam compreender a doença sob a influência de fatores ambientais (temperatura e molhamento), assim como níveis de resistência do hospedeiro e controle da mancha preta dos citros.

\subsection{Material e Métodos}

\subsubsection{Elaboração da escala diagramática}

$\mathrm{Na}$ confecção da escala diagramática, folhas de limão 'Siciliano' com sintomas característicos de mancha preta apresentando variações nos níveis de severidade da doença foram coletadas e fotocopiadas, visando determinar a forma,

distribuição e freqüência das lesões, assim como quantificar a área foliar sadia e a área lesionada. A medida de área lesionada foi obtida após a reprodução das lesões em plástico transparente e a área total foi obtida diretamente por fotocópias que reproduziram o tamanho original das folhas, ambas as áreas foram mensuradas com o auxílio de um medidor de área foliar $\left(\operatorname{LICOR}^{\circledR}\right.$ LI-3000). Os níveis mínimo e máximo foram determinados por dois critérios: os níveis reais observados no campo e por sugestões de pesquisadores experientes na quantificação de doenças dos citros. Os níveis de severidade adotados para cada folha obedeceram ao princípio da lei de "Weber-Fechner", onde acuidade visual é proporcional ao logaritmo da intensidade do estímulo (Horsfall \& Barratt, 1945). Na representação da escala, uma folha de citros de tamanho padrão foi desenhada cinco vezes e os sintomas foram representados por meio de desenhos circulares e irregulares (coalescência de lesões) no programa Paint (Microsoft $\circledast$ ). 


\subsubsection{Validação da escala diagramática}

A validação da escala diagramática consistiu de duas etapas: na primeira

etapa um total de 14 avaliadores distribuídos em dois grupos distintos quanto a experiência ou ausência de experiência na quantificação de doenças de plantas estimaram a severidade da doença em 27 folhas de limão 'Siciliano' com sintomas de mancha preta, sem o uso da escala diagramática. Na segunda etapa, os mesmos avaliadores estimaram a severidade da doença em 30 folhas de limão 'Siciliano', com o auxílio da escala diagramática. A severidade real de todas as folhas utilizadas na validação foi quantificada com medidor de área foliar (LICOR ${ }^{\circledR}$ LI-3000), da mesma forma descrita no item anterior.

\subsubsection{Análise dos dados}

A análise dos dados foi realizada por regressão linear entre a severidade estimada (variável dependente) a severidade real (variável independente) por meio do programa estatístico STATISTICA for Windows 5.0 (StatSoft, Tulsa, OK), onde verificou-se a acurácia e a precisão dos avaliadores. A precisão foi estimada pelo coeficiente de determinação $\left(R^{2}\right)$ da regressão e pela variação dos erros absolutos (severidade estimada menos real) (Godoy et al., 1997; Nutter \& Schultz, 1995; Parker et al., 1995). A acurácia das estimativas de cada avaliador foi determinada pelo teste $t$ aplicado à interseção da regressão linear (a), para verificar se foi significativamente diferente de zero, e ao coeficiente angular da reta $(b)$, para testar se foi significativamente diferente de um, ao nível de probabilidade $p=0,05$ (Parker et al., 1995). A reprodutibilidade das avaliações foi verificada por regressão linear, considerando as estimativas do melhor avaliador de cada grupo como variável independente $(X)$ e as estimativas dos demais avaliadores como variável dependente (Y). Os gráficos foram confeccionados no programa Plot-It 3.1 for Windows (Scientic Programming Enterprises, Haslett, MI). 


\subsection{Resultados e Discussão}

\subsubsection{Escala diagramática para quantificação da severidade da mancha preta em folhas de citros}

Os cinco níveis de severidade da mancha preta dos citros utilizados na elaboração da escala estão representados na Figura 1. Considerando a distribuição de sintomas da doença, os níveis de severidade determinados pelo medidor de área foliar e obedecendo a lei de Weber-Fechner (Horsfall \& Barrat, 1945). Os níveis intermediários correspondem às severidades de $1 ; 3 ; 6 ; 12$ e 24\%.

O valor máximo de severidade da doença representado na escala corrobora com as observações de Kranz (1977) de que muitas mensurações em campo envolvem níveis de severidade inferiores a $30 \%$.

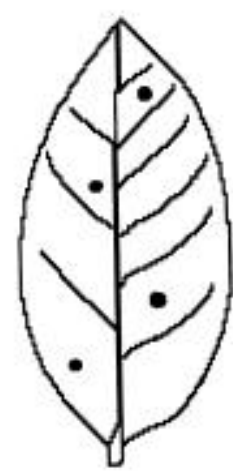

1

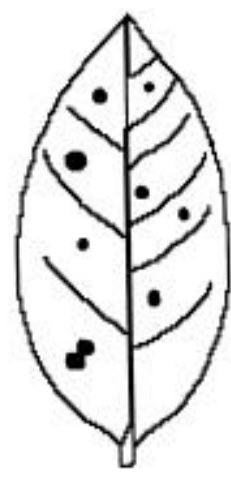

3

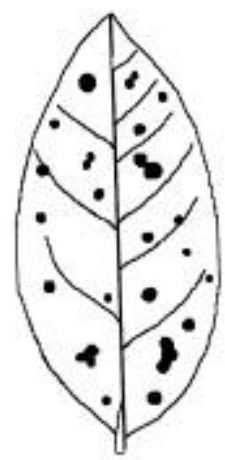

6

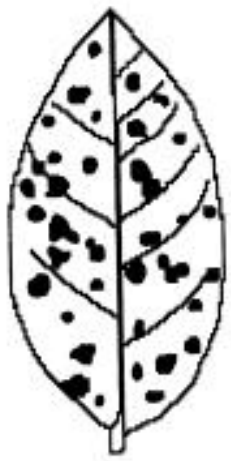

12

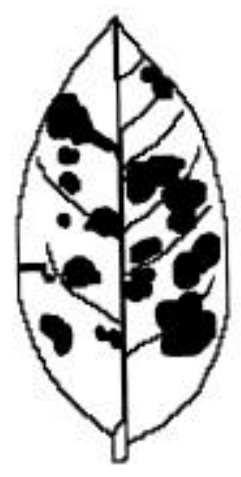

24

Figura 1 - Escala diagramática para avaliação da mancha preta dos citros (Guignardia citricarpa) em folhas de limoeiro com cinco níveis de severidade da doença. 


\subsubsection{Validação da escala diagramática}

$\mathrm{Na}$ primeira etapa da validação, sem o auxílio da escala diagramática, os avaliadores experientes apresentaram uma boa precisão, com coeficientes de determinação variando de 0,51 a 0,90. Entretanto, os avaliadores com menor $R^{2}$ foram mais acurados (C e E), cujos coeficientes angulares da reta de regressão não diferiram da unidade $(p<0,05)$. A maioria dos avaliadores apresentou tendência em superestimar a doença, o que pode ser observado pelos valores de $b$ significativamente maiores que a unidade (Tabela 1). Quanto aos avaliadores inexperientes, o coeficiente de determinação variou de 0,31 a 0,83 , e três avaliadores não superestimaram a doença $(\mathrm{C} \mathrm{e} \mathrm{F)(Tabela} \mathrm{2).}$

Com o auxílio da escala diagramática, dentre todos os avaliadores de ambos os grupos, oito melhoraram sua precisão, enquanto que seis foram menos precisos na estimativa da severidade da mancha preta em folhas de limão 'Siciliano' (Figuras 2 e 3; Tabelas 1 e 2). Quanto à acurácia a escala possibilitou que três avaliadores experientes (A, D e E) apresentassem coeficientes angulares da reta de regressão iguais a unidade $(p<0,05)$, enquanto que para todos os avaliadores inexperientes, os coeficientes angulares diferiram da unidade (Tabelas 1 e 2 ). Ao contrário das avaliações sem escala, houve uma tendência dos avaliadores em subestimar a severidade da doença (Figuras 2 e 3 ).

Estimativas de severidade efetuadas sem o uso da escala por avaliadores experientes e inexperientes explicaram em média, respectivamente $0,67 \%$ e $0,61 \%$ da variação na mensuração da doença, enquanto que com seu uso, a média de variação para ambos os avaliadores, experientes e inexperientes passou para 0,70\% e 0,69\%, respectivamente (Tabelas 1 e 2).

Alguns estudos demonstraram que existe uma certa variabilidade entre avaliadores mesmo com o uso de escalas, de tal forma que a acurácia e a precisão das avaliações são grandemente influenciadas pela habilidade de estimar severidade, própria de cada indivíduo (Godoy et al., 1997; Nutter Jr. \& Schultz, 1995; Amorim, 1993; O’Brien \& van Bruggen, 1992). Weber \& Jorg (1991) relataram que o coeficiente de determinação $\left(R^{2}\right)$ para equações de regressão que relacionam estimativas visuais $(Y)$ com níveis de severidade reais $(X)$ variam de 70 a $95 \%$ entre 
avaliadores. Eles relataram que estimativas visuais da severidade do míldio em folhas de cereais infectadas era até quatro vezes o nível real de severidade. Os coeficientes de determinação obtidos neste trabalho assemelham-se aos resultados encontrados por Michereff et al. (2000) na avaliação da severidade da queima das folhas do inhame (Curvularia eragrostidis) e por Parker et al. (1995) na estimativa da severidade de doenças em folhas de cereais (Septoria tritici, Erysiphe graminis).

Para verificar se o avaliador ou o método promovem avaliações de doença perfeitamente acuradas para todas as unidades amostrais, espera-se que para cada $1 \%$ de aumento na severidade real, o avaliador ou método também estime um aumento de $1 \%$, então a inclinação será igual a 1,0 (nenhum desvio sistemático) e a interseção será igual a zero (nenhum desvio constante) (Nutter \& Schultz, 1995).

Os coeficientes angulares registrados revelam que para cada $1 \%$ de aumento na severidade real, a severidade aumentou em média 1,56 (2,63-0,85) e 1,68\% (2,94 $0,76)$ quando estimada sem o auxílio da escala diagramática por avaliadores experientes e inexperientes, respectivamente, indicando uma tendência à superestimativa da doença e a presença de desvios sistemáticos (Tabelas 1 e 2). Com o uso da escala para cada $1 \%$ de aumento na severidade determinada pelo medidor de área foliar, a severidade foi menor ou igual a um, com médias de 0,99 $(0,49-1,62)$ e $0,84 \% \quad(0,33-1,39)$ para avaliadores experientes e inexperientes, respectivamente (Tabelas 1 e 2). Pode-se, assim verificar que a escala influenciou na acurácia dos avaliadores, alterando a tendência à elevada superestimativa para leves subestimativas, uma vez que os valores dos coeficientes angulares das retas de regressão obtidos com a escala aproximaram-se da unidade. Essa redução observada nos valores médios do coeficiente angular, independentemente do grau de experiência do avaliador, quando se adota a escala diagramática como ferramenta na avaliação da severidade da mancha preta dos citros, torna-se muito importante, pois quando se estima valores altos de severidade da doença, o erro das mensurações é menor. Isso pode ser observado no seguinte exemplo: para um coeficiente angular de 1,68 (valor médio de $b$ para avaliadores inexperientes e sem escala diagramática) e um valor real de severidade igual a 24 (valor máximo da escala diagramática) o erro é de $16 \%$ (24 x 1,68=40,3; 40,3 - 24=16\%), enquanto que quando $b$ é igual a 0,84 (valor médio de $b$ para avaliadores inexperientes com a escala diagramática) o erro é 
de apenas $-3,8 \%$ (24 x 0,84= 20,16;20,16 - 24=-3,8\%). Além de melhorar a acurácia dos dois grupos de avaliadores, a escala possibilitou uma aproximação nas mensurações da doença, efetuadas tanto por avaliadores experientes como inexperientes, proporcionando, assim, uma maior confiabilidade nas medidas de campo, independentemente do grau de experiência do avaliador.

Os valores médios da interseção $(a)$ obtidos sem a escala diagramática foram de 2,79 e 4,55, para os avaliadores experientes e inexperientes respectivamente, enquanto que com o uso da escala diagramática esses valores foram reduzidos para 0,76 e 0,58, para os avaliadores experientes e inexperientes, respectivamente (Tabelas 1 e 2). Percebe-se então que, o valor médio de $a$ foi neglíível com o uso da escala diagramática, reduzindo consideravelmente os desvios constantes e melhorando a acurácia dos dois grupos de avaliadores. Mudanças nos parâmetros inclinação e interseção também podem ser usados para registrar melhorias na acurácia e precisão dos avaliadores (Nutter \& Schultz, 1995).

A presença de desvios sistemáticos e constantes em avaliações visuais de doenças foliares, também foi observada por Nutter et al. (1993) quando avaliaram a acurácia de avaliadores na mensuração da mancha foliar de Agrostis palustris Huds., causada por Sclerotinia homeocarpa F.T. Bennett. Segundo os autores a correção de desvios sistemáticos é importante em patossistemas para os quais decisões de manejo são baseadas em limiares de doença. Nesses casos, um erro na estimativa da doença leva a um erro da mesma magnitude na decisão de aplicar ou não uma medida de controle. 
Tabela 1. Interseção $(a)$, coeficiente angular $(b)$ e coeficiente de determinação $\left(R^{2}\right)$ das regressões lineares entre severidade real e estimada pelos avaliadores experientes sem e com a escala diagramática e média dos parâmetros da equação de regressão, considerando todos os avaliadores.

\begin{tabular}{ccccccc}
\hline \multicolumn{3}{c}{ Experientes sem escala } & \multicolumn{4}{c}{ Experientes com escala } \\
Avaliador & $\mathrm{a}$ & $\mathrm{b}$ & $\mathrm{R}^{2}$ & $\mathrm{a}$ & $\mathrm{b}$ & $\mathrm{R}^{2}$ \\
\hline $\mathrm{A}$ & $-1,28$ & $2,63^{*}$ & 0,79 & 0,41 & 1,16 & 0,54 \\
$\mathrm{~B}$ & $6,84^{*}$ & $2,07^{*}$ & 0,58 & 0,32 & $0,80^{*}$ & 0,80 \\
$\mathrm{C}$ & 2,50 & 1,14 & 0,51 & 0,21 & $0,49^{*}$ & 0,72 \\
$\mathrm{D}$ & 0,76 & $1,60^{*}$ & 0,90 & 0,88 & 1,19 & 0,76 \\
$\mathrm{E}$ & 1,87 & 1,05 & 0,54 & $1,31^{*}$ & 0,86 & 0,72 \\
$\mathrm{~F}$ & $3,84^{*}$ & $1,61^{*}$ & 0,70 & 0,81 & $1,62^{*}$ & 0,61 \\
$\mathrm{G}$ & $2,42^{*}$ & 0,85 & 0,67 & $1,41^{*}$ & $0,78^{*}$ & 0,76 \\
\hline Média & 2,79 & 1,56 & 0,67 & 0,76 & 0,99 & 0,70
\end{tabular}

*asterisco representa situações onde a hipótese de nulidade $(a=0$ ou $b=1)$ foi rejeitada pelo teste $\mathrm{t}, \mathrm{p}<0,05$.

Tabela 2. Interseção (a), coeficiente angular $(b)$ e coeficiente de determinação $\left(R^{2}\right)$ das regressões lineares entre severidade real e estimada pelos avaliadores inexperientes sem e com a escala diagramática e média dos parâmetros da equação de regressão, considerando todos os avaliadores.

\begin{tabular}{ccccccc}
\hline \multicolumn{3}{c}{ Inexperientes sem escala } & \multicolumn{4}{c}{ Inexperientes com escala } \\
Avaliador & $\mathrm{a}$ & $\mathrm{b}$ & $\mathrm{R}^{2}$ & $\mathrm{a}$ & $\mathrm{b}$ & $\mathrm{R}^{2}$ \\
\hline $\mathrm{A}$ & $3,44^{*}$ & $2,94^{*}$ & 0,83 & $1,67^{*}$ & $0,63^{*}$ & 0,58 \\
$\mathrm{~B}$ & 2,43 & $1,78^{*}$ & 0,67 & 0,04 & $1,18^{*}$ & 0,93 \\
$\mathrm{C}$ & $8,48^{*}$ & 1,26 & 0,60 & $1,07^{*}$ & $0,41^{*}$ & 0,48 \\
$\mathrm{D}$ & $6,67^{*}$ & $1,38^{*}$ & 0,73 & $0,45^{*}$ & $0,33^{*}$ & 0,62 \\
$\mathrm{E}$ & $8,46^{*}$ & 0,76 & 0,31 & $-0,25$ & $1,34^{*}$ & 0,79 \\
$\mathrm{~F}$ & 0,07 & 1,41 & 0,59 & 0,14 & $1,34^{*}$ & 0,70 \\
$\mathrm{G}$ & 2,30 & $2,21^{*}$ & 0,55 & 0,45 & $0,63^{*}$ & 0,76 \\
\hline Média & 4,55 & 1,68 & 0,61 & 0,58 & 0,84 & 0,69
\end{tabular}

*asterisco representa situações onde a hipótese de nulidade $(a=0$ ou $b=1)$ foi rejeitada pelo teste $\mathrm{t}, \mathrm{p}<0,05$. 


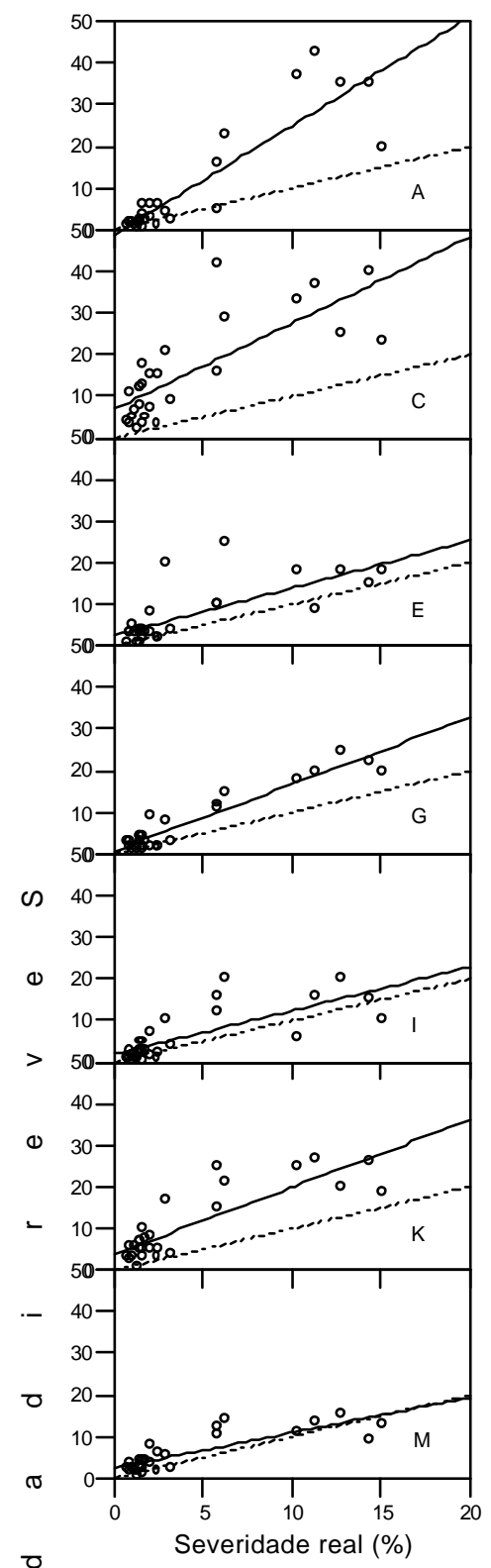

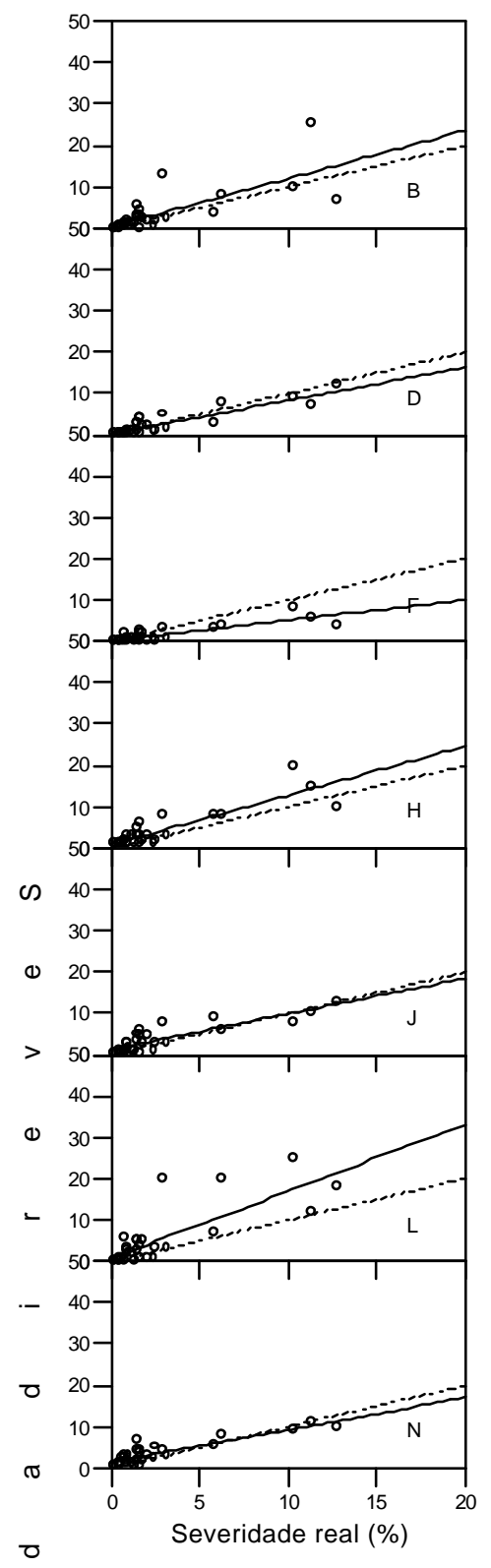

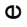

Figura 2 - Regressões lineares entre severidades real e estimada por avaladores experientes sem (A,C,E,G,I,K,M) e com o auxílio da escala diagramática $(\mathrm{B}, \mathrm{D}, \mathrm{F}, \mathrm{H}, \mathrm{J}, \mathrm{L}, \mathrm{N})$. A linha tracejada representa a estimativa real da severidade e a linha cheia a estimativa visual de cada avaliador. 


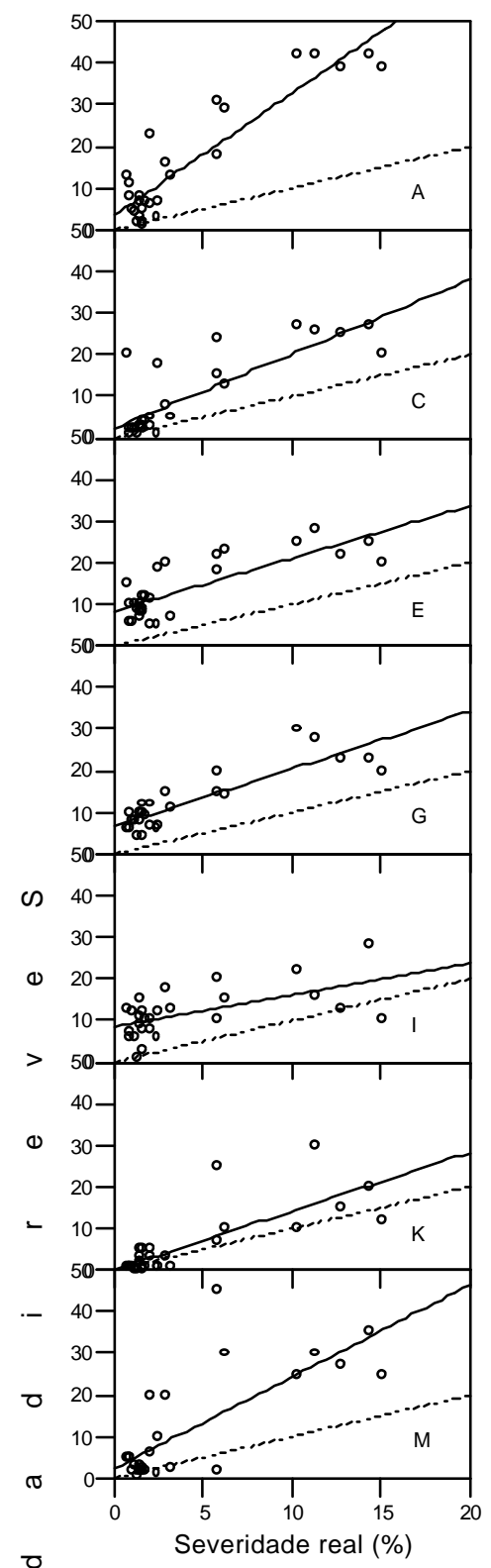

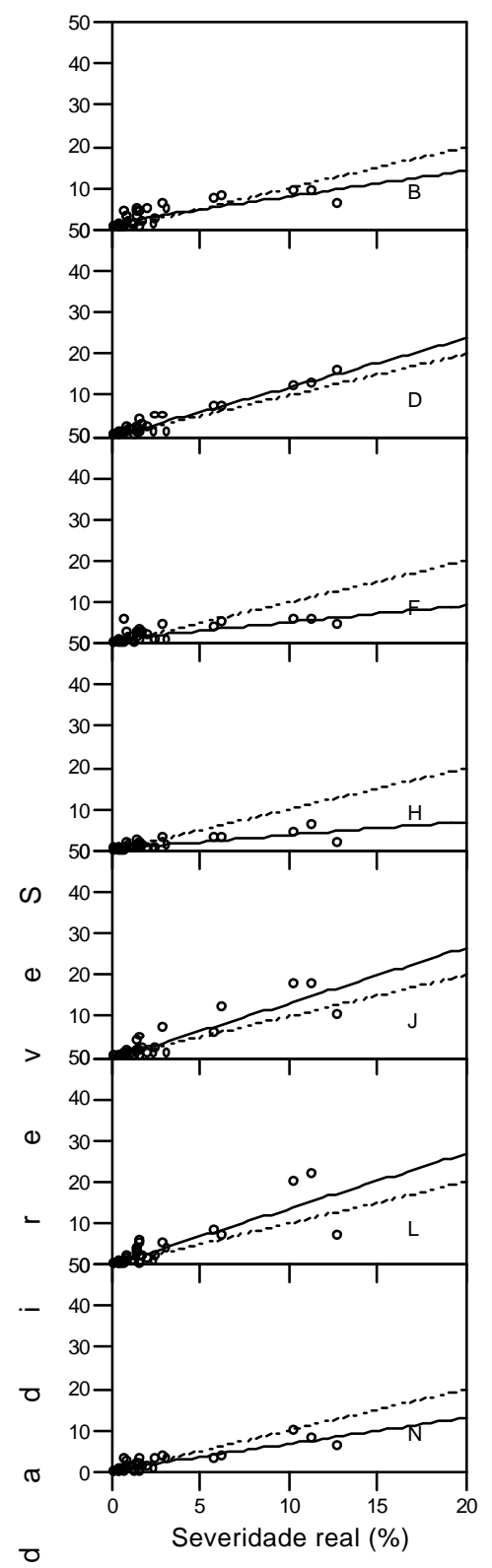

Figura 3 - Regressões lineares entre severidades real e estimada por avaliadores inexperientes sem (A,C,E,G,I,K,M) e com o auxílio da escala diagramática $(\mathrm{B}, \mathrm{D}, \mathrm{F}, \mathrm{H}, \mathrm{J}, \mathrm{L}, \mathrm{N})$. A linha tracejada representa a estimativa real da severidade e a linha cheia a estimativa visual de cada avaliador. 
Os erros absolutos (resíduos) encontrados pelas diferenças entre os valores estimados visualmente e aqueles determinados pelo medidor de área, para avaliadores experientes sem o auxílio da escala diagramática, variam de $-5,31$ a 36,14 (Figura 4C e 4M). Com o uso da escala diagramática os avaliadores experientes apresentaram erros absolutos entre $-8,70$ a 17,11 (Figura 4C e 4L). Para avaliadores inexperientes, nas estimativas da severidade da doença sem a escala diagramática, o erro absoluto variou entre $-5,06$ a 39,14 (Figura 5I e 5M), enquanto que com o auxílio da escala diagramática, os erros absolutos ficaram na faixa de 10,7 a 10,66 (Figura 5H e 5L). Para ambos os grupos de avaliadores, na maioria dos casos, os desvios foram mais evidentes para níveis de severidade entre 5 e $15 \%$ (Figuras 4 e 5). Contudo, pode-se verificar que a escala proporcionou uma redução nos erros absolutos, e para a maioria dos avaliadores os erros absolutos concentraram-se numa faixa aceitável, segundo critérios adotados nos programas Distrain (Tomerlin \& Howell, 1988) e Disease.Pro (Nutter e Worawitlikit, 1989) utilizados para o treinamento na quantificação de doenças. Uma das possíveis razões da origem desses desvios deve-se à dificuldade dos avaliadores em estimar áreas lesionadas circundadas por halos amarelos que na maioria das vezes conduz a sub ou superestimativas da doença. Parker et al. (1995), avaliando a confiabilidade de estimativas visuais da severidade da doença causada por Septoria tritici em folhas de cereais, verificaram que a considerável inacurácia observada nas estimativas da doença foi provavelmente devida ao elevado nível de senescência das folhas avaliadas. Ainda, segundo os autores distinguir o limite entre necrose de doença e senescência fisiológica é um problema específico em avaliações de Septoria tritici, e isto pode ter contribuído para baixa precisão e pouca consistência dos observadores. 

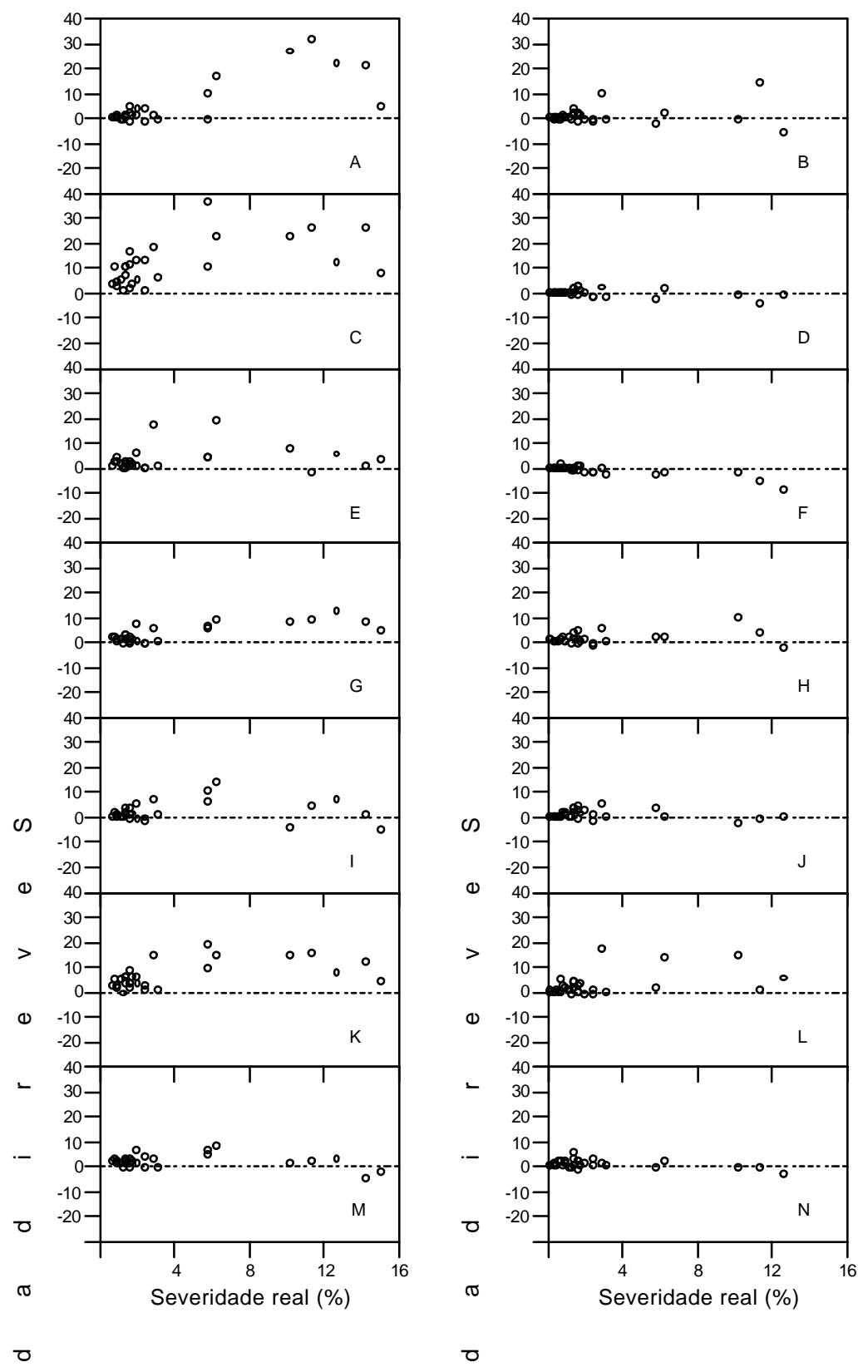

Figura $^{\circledR} 4$ - Erros absolutos (diferençå entre severidades estimada e real) dos avaliadores experientes sem (A,C,E,G,I,K,M) e com o auxílio da escala diagramática (B,D,F,H,J,L,N). 

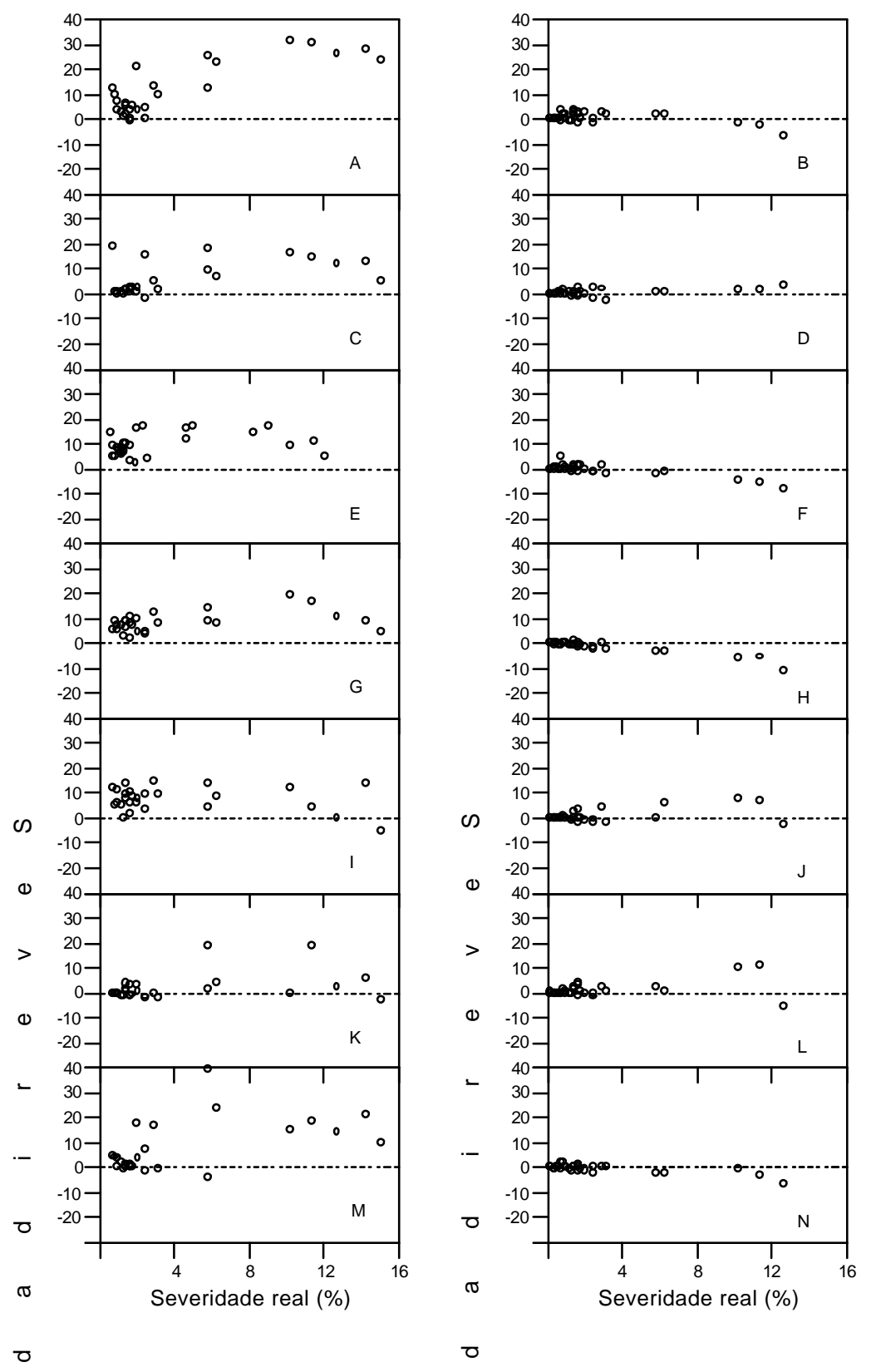

Figura $^{\circledR} 5$ - Erros absolutos (diferenças entre severidades estimada e real) dos avaliadores inexperientes sem (A,C,E,G,I,K,M) e com o auxílio da escala diagramática (B,D,F,H,J,L,N). 
As regressões lineares estimadas entre o melhor avaliador experiente e os demais avaliadores originaram coeficientes de determinação satisfatórios $\left(R^{2}>0,7\right)$, com níveis de precisão uniformes para a maioria dos avaliadores, e coeficientes angulares que não diferiram significativamente da unidade $(\mathrm{p}<0,05)$ para três das seis combinações (Tabela 3). Esta reprodutibilidade das avaliações entre o melhor avaliador e os demais, representa mais um indicativo de precisão e acurácia de um método de avaliação de doenças (Nutter \& Schultz, 1995). Quando se comparou as estimativas do melhor avaliador inexperiente com os demais do mesmo grupo, os coeficientes de determinação variaram de 0,52 a 0,79, havendo assim diferenças consideráveis de precisão entre avaliadores. Apenas dois avaliadores apresentaram coeficientes angulares iguais a unidade $(\mathrm{p}<0,05)($ Tabela 4$)$.

Tabela 3. Interseção $(a)$, coeficiente angular $(b)$ e coeficiente de determinação $\left(R^{2}\right)$ das regressões lineares entre a severidade estimada pelo melhor avaliador experiente com as estimativas dos demais avaliadores.

\begin{tabular}{cccc}
\hline \multirow{2}{*}{ Avaliador } & $\mathrm{a}$ & $\mathrm{b}$ & $\mathrm{R}^{2}$ \\
\hline $\mathrm{A}$ & 0,52 & 1,20 & 0,46 \\
$\mathrm{C}$ & 0,18 & $0,54^{*}$ & 0,71 \\
$\mathrm{D}$ & 0,87 & 1,28 & 0,71 \\
$\mathrm{E}$ & $1,12^{*}$ & 1,00 & 0,79 \\
$\mathrm{~F}$ & 0,17 & $2,00^{*}$ & 0,76 \\
$\mathrm{G}$ & $1,39^{*}$ & $0,84^{*}$ & 0,73 \\
\hline
\end{tabular}

*asterisco representa situações onde a hipótese de nulidade $(a=0$ ou $b=1)$ foi rejeitada pelo teste $\mathrm{t}, \mathrm{p}<0,05$. 
Tabela 4. Interseção $(a)$, coeficiente angular $(b)$ e coeficiente de determinação $\left(R^{2}\right)$ das regressões lineares entre a severidade estimada pelo melhor avaliador inexperiente com as estimativas dos demais avaliadores.

\begin{tabular}{cccc}
\hline \multicolumn{4}{c}{ Inexperientes } \\
Avaliador & $\mathrm{a}$ & $\mathrm{b}$ & $\mathrm{R}^{2}$ \\
$\mathrm{~A}$ & $1,74^{*}$ & $0,51^{*}$ & 0,56 \\
$\mathrm{C}$ & $1,06^{*}$ & $0,34^{*}$ & 0,52 \\
$\mathrm{D}$ & $0,49^{*}$ & $0,27^{*}$ & 0,59 \\
$\mathrm{E}$ & $-0,16$ & 1,10 & 0,79 \\
$\mathrm{~F}$ & 0,33 & 1,06 & 0,65 \\
$\mathrm{G}$ & 0,47 & $0,51^{*}$ & 0,77 \\
*asterisco representa situações onde a hipótese de nulidade $(\mathrm{a}=0$ ou $\mathrm{b}=1)$ foi \\
rejeitada pelo teste $\mathrm{t}, \mathrm{p}<0,05$.
\end{tabular}

De acordo com os dados obtidos sem e com o uso da escala diagramática na avaliação da severidade da mancha preta dos citros em folhas de limão 'Siciliano', pode-se constatar que o uso da escala proporcionou melhor precisão e acurácia tanto para avaliadores experientes como inexperientes, considerando-se a média dos avaliadores. A experiência dos avaliadores teve menor influência na avaliação da doença que o uso da escala, de modo que a escala diagramática proposta neste trabalho pode ser recomendada em avaliações para quantificação da severidade da mancha preta em folhas de citros.

\subsection{Conclusão}

A utilização da escala diagramática para avaliação da severidade da mancha preta dos citros em folhas de limão 'Siciliano', possibilita estimativas da severidade da doença mais precisas e acuradas, independentemente do nível de experiência dos avaliadores. 


\section{EFEITO DA TEMPERATURA E DA DURAÇÃO DO MOLHAMENTO NA PRÉ-PENETRAÇÃO DE CONÍDIOS DE Guignardia citricarpa Kiely [Phyllosticta citricarpa (McAlp.) Van der Aa ]}

\section{Resumo}

Os efeitos da temperatura $\left(10{ }^{\circ} \mathrm{C}-40{ }^{\circ} \mathrm{C}\right)$ e da duração do molhamento $(12$ - 48 h) na formação de apressórios de conídios de Guignardia citricarpa (Phyllosticta citricarpa) foram quantificados em ambiente controlado, sob condições "in vitro" e na superfície de folhas de limão 'Siciliano'. O efeito da temperatura na formação de apressórios foi explicado pela função beta generalizada e o molhamento, pelo modelo monomolecular. A formação de apressórios ocorreu em todas as temperaturas a partir de 12 horas de molhamento. A temperatura mínima para formação de apressórios, estimada pela função beta generalizada, foi de $3{ }^{\circ} \mathrm{C}$ e a máxima, de $48,4{ }^{\circ} \mathrm{C}$, ambas para 48 horas de molhamento. A duração do período de molhamento proporcionou um aumento na formação de apressórios, com o máximo de apressórios formados a 24 horas de molhamento, para a maioria das temperaturas. O período de molhamento de 48 horas foi fundamental para que os esporos submetidos a temperaturas de $10{ }^{\circ} \mathrm{C}$ e $40{ }^{\circ} \mathrm{C}$ formassem apressórios. A superfície de resposta obtida pela multiplicação das funções beta generalizada e monomolecular teve um bom ajuste para os dados encontrados $\left(R^{2}=0,75\right)$. As amostras observadas em microscopia eletrônica de varredura possibilitaram a aquisição de imagens de conídios germinados e com apressórios sobre a superfície de folhas de limão 'Siciliano' em todas as combinações de temperatura e molhamento. 


\section{Effect of temperature and wetness duration on pre-penetration of conidia of Guignardia citricarpa Kiely [Phyllosticta citricarpa (McAlp.) van der Aa ]}

\section{Summary}

The effect of temperature $\left(10{ }^{\circ} \mathrm{C}-40{ }^{\circ} \mathrm{C}\right)$ and wetness duration $(12 \mathrm{~h}-48 \mathrm{~h})$ in the formation of appressorium of conidia of Guignardia citricarpa (Phyllosticta citricarpa) were quantified by "in vitro" trials and in of lemon 'Siciliano' leaves, under controlled environment. The effect of temperature on appressorium formation was explained by the generalized beta function and the effect of wetness duration by the monomolecular model. Appressoria were formed under all the tested temperatures starting from 12 hours of wetness. The extreme temperatures $\left(10^{\circ} \mathrm{C}\right.$ and $\left.40{ }^{\circ} \mathrm{C}\right)$ were less favorable to the apressorium formation. The minimum temperature for appressorium formation, estimated by generalized beta function was of $3{ }^{\circ} \mathrm{C}$ and the maximum of $48,4{ }^{\circ} \mathrm{C}$, both for 48 hours of wetness. The wetness duration period provided an increase in the appressorium formation, with the maximum of appressorium formed at 24 hours of wetness, for majority of the temperatures. The wetness duration period of 48 hours was fundamental so that the spores submitted to temperatures of $10{ }^{\circ} \mathrm{C}$ and $40{ }^{\circ} \mathrm{C}$, formed appressorium. The response surface obtained by the multiplication of the generalized beta and monomolecular functions provided a close fit to observed data $\left(R^{2}=0,75\right)$. Except for a damaged sample during its preparation, all the other samples were observed at scanning electron microscope. Images of germinating conidia and appressoria on the surface of lemon 'Siciliano' leaves were taken in all the temperature combinations and wetness. 


\subsection{Introdução}

A citricultura brasileira ocupa um lugar de destaque no mercado agro-industrial, devido ao seu volume de produção, à geração de divisas e por sua importância estratégica na economia, principalmente, no Estado de São Paulo, maior produtor de frutas cítricas (FNP Consultoria \& Comércio, 2001).

A mancha preta dos citros, doença causada pelo fungo Guignardia citricarpa Kiely, cuja forma anamórfica corresponde a Phyllosticta citricarpa (McAlp.) van der Aa (sin.= Phyllosticta citricarpa (McAlp.) Petrak.) foi descrita no Brasil, em 1980 (Robbs et al., 1980), afetando pomares comerciais em São Gonçalo e Itaboraí, no Estado do Rio de Janeiro. Em 1992 foi constatada pela primeira vez em pomares paulistas e atualmente é relatada em 44 municípios, podendo, entretanto, ter abrangência geográfica ainda maior (Fundecitrus, 1998). Severas epidemias têm sido constatadas em diferentes municípios do Estado de São Paulo (Goes et al., 2000).

Embora ascósporos sejam considerados em trabalhos internacionais como o inóculo mais importante, a possibilidade de infecções significativas por conídios sob algumas circunstâncias não pode ser desconsiderada (McOnie, 1964a), pois a importância relativa destas duas formas de inóculo tem sido muitas vezes mal interpretada (Kotzé, 1996).

Os ascósporos e os conídios germinam na superfície de órgãos suscetíveis e produzem tubo germinativo e apressório do qual se origina um delgado "peg" de penetração que penetra a cutícula, dando origem a uma pequena massa de micélio entre a cutícula e a epiderme do órgão infectado (McOnie, 1967; Kotzé, 1988). Fatores como radiação solar intensa e altas temperaturas são fundamentais na manifestação dos sintomas da mancha preta (Kotzé, 1981; 1996).

Poucos estudos foram realizados com a forma conidial, embora ela seja a principal responsável pela disseminação do patógeno a curta distância. Conídios produzidos em picnídios formados em lesões de frutos e folhas emergem através de um ostíolo, envolvidos sempre por uma substância mucilaginosa. A água em contato com a superfície dessas estruturas, solubiliza a mucilagem e carrega os conídios em suspensão 
até a superfície de órgãos suscetíveis próximos, onde novas infecções ocorrem (Kotzé, 1981; 1988; Robbs et al., 1985). A coexistência de frutos infectados nas plantas e de frutos jovens suscetíveis fazem dos conídios agentes importantes na epidemiologia da mancha preta (Kotzé, 1963). Hoto et al. (2001), acompanhando o processo ontogênico de picnídios, observaram que 21 dias após sua formação os picnídios estavam vazios, indicando que a completa liberação de conídios ocorre antes deste período.

Temperaturas desfavoráveis podem prolongar o período de latência e desta forma influenciar no número de gerações de esporos que ocorrem durante uma estação. Este efeito no fornecimento de inóculo pode determinar se uma epidemia deverá ou não se desenvolver (Colhoun, 1973). Brodrick \& Rabie (1970), avaliando a influência de duas temperaturas $\left(20\right.$ e $\left.27{ }^{\circ} \mathrm{C}\right)$ e diferentes regimes de luz na produção de lesões em frutos de laranja 'Valência' e na esporulação de conídios de G. citricarpa em meio de cultura artificial, observaram que para a expressão dos sintomas da mancha preta a temperatura mais favorável foi de $27{ }^{\circ} \mathrm{C}$, enquanto que a esporulação "in vitro" foi maior a $20{ }^{\circ} \mathrm{C}$ de temperatura.

Kiely (1948) relatou que ascósporos requerem mais que 24 horas para germinar e aproximadamente 48 horas para desenvolver apressório. McOnie (1967), avaliando a germinação e formação de apressório de ascósporos de G. citricarpa, verificou que a taxa de formação de apressório foi extremamente variável, embora o tempo de formação de apressório tenha sido consideravelmente mais rápido que o relatado por Kiely (1948). Segundo McOnie (1967), até 11 horas não havia ocorrido formação de apressório, enquanto que após 18 horas, 48\% dos ascósporos tinham desenvolvido apressório.

Timossi (2000), avaliando a influência da temperatura e do tempo de incubação na germinação de ascósporos de G. citricarpa, observou que as maiores médias foram obtidas nas temperaturas de 21 e $24{ }^{\circ} \mathrm{C}$, no tempo máximo observado de 18 horas de incubação, sob ausência de luz, enquanto que nas temperaturas extremas de 15 e $33{ }^{\circ} \mathrm{C}$, verificou-se os menores percentuais de germinação.

Fungos parasitas de plantas conquistam a planta viva como uma fonte abundante de nutrientes. Para o sucesso do parasitismo, um passo crucial é a penetração. Para superar as várias barreiras presentes em folhas, frutos, talos, ou raízes, os fungos 
possuem diversas estratégias de invasão. Com este propósito estruturas de infecção são produzidas o que permite a penetração do fungo em diferentes tipos de parede celular da planta. Sinais químicos como íons potássio e cálcio, açúcares simples, gradientes de $\mathrm{pH}$, bem como mudanças de temperatura induzem a formação de apressório, porém seu significado ainda é obscuro (Mendgen et al., 1996).

A iniciação, formação e ação do apressório são partes integrais do processo de infecção de muitos fungos parasitas. Em algumas espécies, a formação de apressório pode ser obrigatória para a infecção, enquanto que em outras isto pode ser opcional ou desnecessário. Populações de esporos da mesma espécie podem ser compostas de diferentes genótipos que requerem diferentes condições ambientais para a germinação (Nair \& Ellingboe, 1965). Além disso, as condições ambientais sob as quais os esporos se desenvolvem podem determinar seus requerimentos para germinação. É possível, então, que nem todos os esporos em uma população sejam homogêneos quanto às condições requeridas para formação de apressório (Emmett \& Parbery, 1975).

Huber \& Gillespie (1990) relataram que para o desencadeamento do processo infeccioso, as horas de molhamento requeridas por diferentes gêneros e espécies de fungos fitopatogênicos estão distribuídas dentro de uma ampla faixa, variando de 0,5 a 100 horas de molhamento foliar.

Embora o significado econômico da mancha preta dos citros já tenha sido reconhecido por um longo período, informações detalhadas a respeito de sua epidemiologia é limitada e controversa (Kotzé, 1996). Este trabalho constitui-se na tentativa de ampliar o conhecimento sobre o processo infeccioso da mancha preta dos citros, especialmente no que se refere à importância dos conídios na epidemia da doença e conseqüientemente no seu controle. Estudos epidemiológicos são vistos, hoje, como uma combinação de pesquisa holística, baseada em ensaios de campo, com experimentação mais refinada e detalhista, baseada em ensaios feitos em condições controladas.

Os objetivos deste trabalho foram determinar o efeito da temperatura e da duração do molhamento na formação de apressórios de conídios de G.citricarpa ( $P$. citricarpa) e observar através de microscopia eletrônica de varredura a germinação e 
formação de apressórios de conídios de G.citricarpa ( $P$. citricarpa) sobre folhas destacadas de limão 'Siciliano', submetidas a diferentes temperaturas e períodos de molhamento.

\subsection{Material e Métodos}

\subsubsection{Instalação dos Ensaios}

Os experimentos foram realizados no laboratório de Epidemiologia do Departamento de Entomologia, Fitopatologia e Zoologia Agrícola e no Núcleo de Apoio à Pesquisa em Microscopia Eletrônica Aplicada à Pesquisa Agropecuária (NAP/MEPA) da Escola Superior de Agricultura "Luiz de Queiroz" - ESALQ/USP, em Piracicaba.

\subsubsection{Obtenção e preparo do inóculo}

O isolado de Guignardia citricarpa (Phyllosticta citricarpa), IAC 13/96, empregado nos ensaios foi gentilmente cedido pelo pesquisador Carlos Ivan AguilarVildoso do Centro APTA Citros Sylvio Moreira - IAC. O fungo foi cultivado nos meios de cultura batata-dextrose-ágar e cenoura-dextrose-ágar, sob luz constante e temperatura ambiente de $\pm 25^{\circ} \mathrm{C}$. Após a obtenção de colônias do isolado, conforme metodologia desenvolvida por Aguilar-Vildoso \& Azevedo (2001), discos de meio de cultura com 5 $\mathrm{mm}$ de diâmetro, contendo crescimento fúngico, e discos de folhas de citros com $17 \mathrm{~mm}$ de diâmetro, previamente autoclavadas, foram justapostos sobre a superfície do meio de cultura ágar-água (3\%) e incubados por 18 dias a $25 \pm 2{ }^{\circ} \mathrm{C}$, sob luz contínua, afim de possibilitar a formação de picnídios e liberação de conídios.

No preparo da suspensão de conídios, uma massa de esporos mucilaginosa, liberada a partir dos picnídios, foi coletada com auxílio de uma ponta de agulha de seringa e depositada em água destilada esterilizada, a qual em seguida foi adicionada à suspensão sacarose (30 g/1000 mL) (Pascholati, comunicação pessoal). 


\subsubsection{Efeito da temperatura e da duração do molhamento na formação de apressórios de Guignardia citricarpa (Phyllosticta citricarpa) "in vitro"}

$\mathrm{Na}$ execução deste ensaio, lâminas de poliestireno foram previamente confeccionadas pela adição em um recipiente de vidro de fragmentos de placa de poliestireno em $100 \mathrm{~mL}$ de acetato de amila. Após três dias, lâminas de vidro foram imersas no líquido formado e postas para secar por cinco horas em capela de exaustão. Antes de serem usadas, as lâminas de poliestireno foram colocadas na câmara de fluxo laminar por uma hora, com o propósito de eliminar algum resíduo do acetato de amila.

Após o preparo da suspensão de conídios, alíquotas de $40 \mu \mathrm{l}$ da suspensão foram pipetadas e depositadas sobre lâminas de poliestireno, as quais foram, em seguida, colocadas sobre um suporte de vidro dentro de placas de Petri contendo papel de filtro umedecido. As placas foram incubadas em câmaras de crescimento (Conviron, modelo E7) com temperaturas ajustadas para $10,15,20,25,30,35$ e $40{ }^{\circ} \mathrm{C}$ e para períodos de molhamentos constituídos de câmara úmida por 12, 24, 36 e 48 horas sob alternância de luz (12 horas claro/12 horas escuro). Para a interrupção do processo de germinação foram adicionados $15 \mu \mathrm{l}$ de lactoglicerol à suspensão fúngica a cada 12 horas, totalizando 48 horas de incubação para cada temperatura. A contagem do número de apressórios foi realizada no microscópio óptico com contraste de fase em aumento de 400 vezes.

O delineamento estatístico utilizado foi inteiramente casualizado, com 28 tratamentos e quatro repetições, sendo cada repetição constituída por uma gota da suspensão na lâmina de poliestireno, onde a contagem de 50 esporos representou $100 \%$. O experimento foi repetido duas vezes.

Posteriormente, com a finalidade de verificar se ocorria a formação de apressórios sob períodos de molhamento inferiores a 12 horas, foi realizado um ensaio adotando 15,25 e $35{ }^{\circ} \mathrm{C}$ de temperatura e períodos de molhamento que corresponderam a 4, 8 e 12 horas. O delineamento estatístico utilizado foi inteiramente casualizado, com nove tratamentos e quatro repetições. A metodologia adotada foi semelhante à descrita 
anteriormente. Os dados deste ensaio foram usados na confecção de uma superfície de resposta.

\subsubsection{Análise dos dados}

Os dados obtidos no ensaio foram analisados por meio de regressões nãolineares, utilizando o programa STATISTICA versão 5.0 (StatSoft, Tulsa, OK) e o PlotIt 3.1 For Windows (Scientic Programming Enterprises, Haslett, MI) para elaboração dos gráficos. O efeito da temperatura sobre a formação de apressório de G. citricarpa ( $P$. citricarpa $)$ foi descrito pela função beta generalizada $Y=B_{1}\left(\left(X-B_{2}\right)^{\wedge} B_{4}\right)\left(\left(B_{3}-X\right)^{\wedge} B_{5}\right)$, descrita por Hau \& Kranz (1990), onde $Y$ representa a quantidade relativa de apressórios formados, $X$ representa a temperatura e os parâmetros $B_{2}$ e $B_{3}$ representam respectivamente, as temperaturas mínima e máxima. Os parâmetros $B_{1}, B_{4}$ e $B_{5}$ não possuem significado biológico. O efeito do período de molhamento na formação de apressórios de $G$. citricarpa ( $P$. citricarpa) foi descrito pelo modelo monomolecular $Y=B_{1}\left(1-B_{2} \exp \left(-B_{3} X\right)\right)$ (Bergamin Filho, 1995), onde $Y$ é a porcentagem relativa de apressórios formados, $X$ é a duração do molhamento, $B_{1}$ é a estimativa da assíntota máxima, $B_{2}$ é um parâmetro do modelo e $B_{3}$ é a taxa de progresso da formação de apressórios. As funções beta generalizada e monomolecular, obtidas nos ensaios com diferentes temperaturas e períodos de molhamento, respectivamente, foram multiplicadas para elaboração de uma superfície de resposta que possibilitou verificar o efeito de diferentes combinações de temperatura e molhamento na formação de apressórios de conídios de G. citricarpa (P. citricarpa). 


\subsubsection{Observação ao microscópio eletrônico de varredura da geminação e formação de apressórios de conídios de Guignardia citricarpa (Phyllosticta citricarpa) sobre folhas destacadas de limão 'Siciliano' submetidas a diferentes temperaturas e períodos de molhamento}

Folhas de limão 'Siciliano' foram destacadas de plantas envasadas, lavadas em água corrente e destilada e, em seguida, colocadas em câmara úmida, constituída de placas de Petri contendo meio ágar-água e papel de filtro estéril umedecido com água destilada esterilizada. Após o preparo da suspensão de conídios, conforme descrito anteriormente, alíquotas de $40 \mu \mathrm{l}$ da suspensão foram pipetadas e depositadas sobre a superfície das folhas. As placas foram incubadas em câmaras de crescimento (Conviron, modelo E7) com temperaturas ajustadas para 15,25 e $35{ }^{\circ} \mathrm{C}$ e molhamentos constituídos de câmara úmida por 12, 24 e 48 horas sob alternância de luz (12 horas claro/12 horas escuro). Após os respectivos períodos de molhamento, as amostras constituídas por fragmentos das folhas, onde estava contida a suspensão fúngica, fram submetidas a um protocolo destinado à observação em microscópio eletrônico de varredura. O protocolo constou de sete etapas: a) fixação do material em Karnovsky modificado (glutaraldeído 2,5\%, formaldeído 2,5\% em tampão cacodilato de sódio $0,05 \mathrm{~m}, \mathrm{pH} 7,2, \mathrm{CaCh}_{2} 0,001$ M); b) lavagem (três passagens das amostras em tampão cacodilato 0,05 M); c) pósfixação em tetróxido de ósmio 1\%; d) desidratação em concentrações crescentes de acetona $\left(30,50,70,90\right.$ e 100\%); e) secagem ao ponto crítico $\left(\mathrm{CO}_{2}\right)$; f) montagem em suporte; g) metalização com ouro (Kitajima \& Leite, 1999). As imagens foram elétronmicrografadas em microscópico eletrônico de varredura (ZEISS Germany, modelo DSM940A). 


\subsection{Resultados e Discussão}

\subsubsection{Efeito da temperatura e da duração do molhamento na formação de apressórios de Guignardia citricarpa (Phyllosticta citricarpa) "in vitro"}

A formação de apressórios de G. citricarpa (P. citricarpa) ocorreu sob uma grande amplitude de temperatura, variando de 10 a $40{ }^{\circ} \mathrm{C}$, como pode ser verificado pelos ajustes da função beta generalizada (Figura 1 e Tabela 1). A maior percentagem relativa de apressórios formados ocorreu a $30{ }^{\circ} \mathrm{C}$ nos diferentes períodos de molhamento, excetuando-se o período de 48 horas. Os extremos de temperatura testados, de $10{ }^{\circ} \mathrm{C}$ e $40{ }^{\circ} \mathrm{C}$ foram menos favoráveis à formação de apressórios, sobretudo $10{ }^{\circ} \mathrm{C}$, onde após 48 horas de molhamento, apenas 24,5\% dos conídios apresentaram apressório (Figura 1). A temperatura mínima para formação de apressórios, estimada pela função beta generalizada foi de $3{ }^{\circ} \mathrm{C}$ e a máxima de $48,4{ }^{\circ} \mathrm{C}$, ambas para 48 horas de molhamento. Considerando o período máximo de incubação, podemos afirmar que a amplitude ou faixa de temperatura favorável à pré-infecção de conídos de G. citricarpa (P. citricarpa) em citros varia de 15 a $35^{\circ} \mathrm{C}$.

A duração do período de molhamento favoreceu a formação de apressórios de $G$. citricarpa (P. citricarpa), conforme descrito pelo modelo monomolecular (Figura 2 e Tabela 2). A partir de 12 horas de molhamento, 31,25\% dos conídios submetidos a $30{ }^{\circ} \mathrm{C}$ haviam formado apressórios. O pico de formação de apressórios ocorreu com 24 horas de molhamento para a maioria das temperaturas. Após 36 horas de molhamento a velocidade de formação de apressórios foi sendo reduzida (Figura 2). O período de molhamento constituído de 48 horas foi fundamental para que os esporos submetidos a temperaturas de $10{ }^{\circ} \mathrm{C}$ e $40{ }^{\circ} \mathrm{C}$, alcançassem $24,51 \%$ e $48,48 \%$ de germinação e formação de apressórios, respectivamente (Figura 2). 

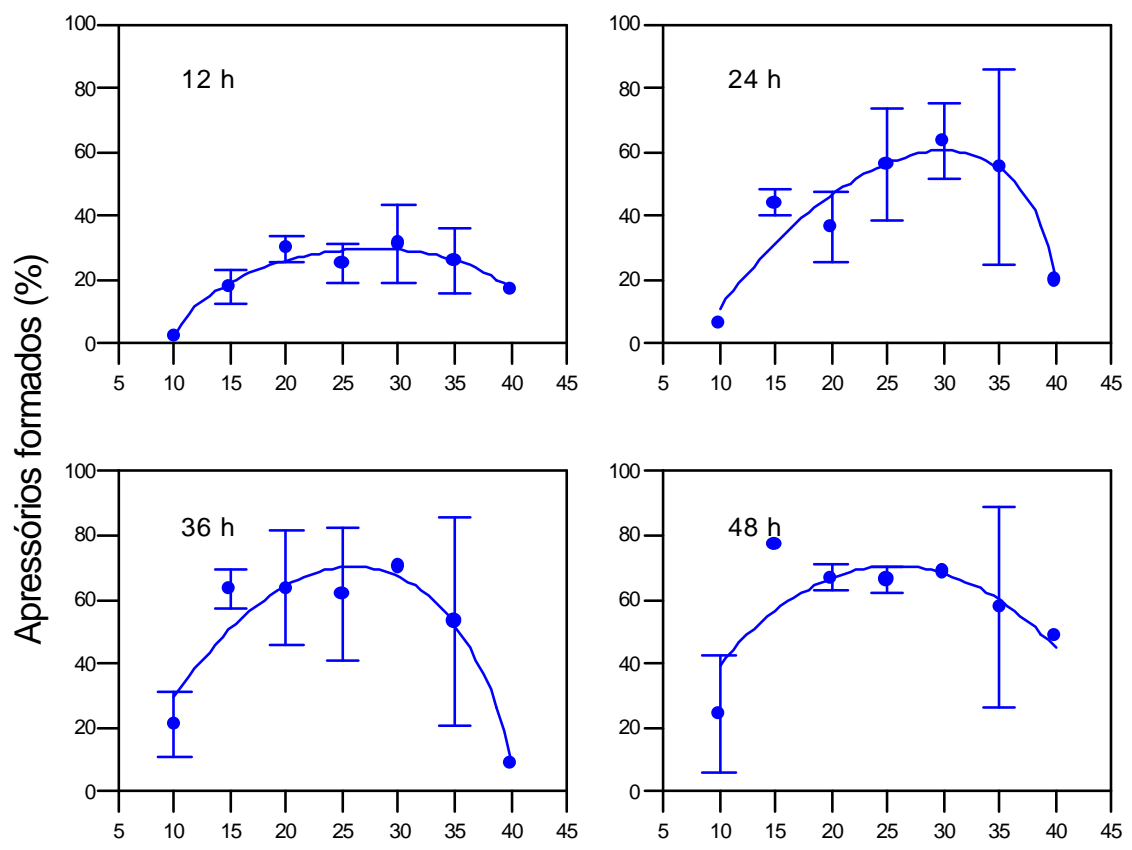

Temperatura (C)

Figura 1 - Porcentagem relativa de apressórios de Guignardia citricarpa (Phyllosticta citricarpa) formados em função de diferentes temperaturas $(10,15,20,25$, 30,35 e $40{ }^{\circ} \mathrm{C}$ ) e períodos de molhamento (12, 24, 36 e 48 horas). Pontos representam as médias e barras o erro médio de dois experimentos. A linha representa ajuste obtido com a função beta generalizada. 
Tabela 1. Coeficientes de determinação $\left(R^{2}\right)$ e parâmetros da função beta generalizada, $Y=B_{1}\left(\left(T-B_{2}\right)^{\wedge} B_{4}\right)\left(\left(B_{3}-T\right)^{\wedge} B_{5}\right)$, onde $Y$ é a porcentagem relativa de apressórios formados, $T$ é a temperatura, os parâmetros $B_{2} e B_{3}$, são respectivamente, as temperaturas mínima e máxima e $B_{1}, B_{4} e B_{5}$ são parâmetros da equação sem significado biológico, ajustada para os diferentes períodos de molhamento.

\begin{tabular}{ccccccc}
\hline Duração do molhamento & $\boldsymbol{B}_{1}$ & $\boldsymbol{B}_{\mathbf{2}}$ & $\boldsymbol{B}_{\mathbf{3}}$ & $\boldsymbol{B}_{\mathbf{4}}$ & $\boldsymbol{B}_{\mathbf{5}}$ & $\boldsymbol{R}^{\mathbf{2}}$ \\
\hline 12 horas & 1,34 & 9,88 & 42,48 & 0,60 & 0,50 & 0,94 \\
24 horas & 1,38 & 8,02 & 40,34 & 0,90 & 0,42 & 0,89 \\
36 horas & 0,78 & 5,00 & 40,24 & 0,93 & 0,63 & 0,91 \\
48 horas & 0,27 & 3,00 & 48,41 & 0,89 & 0,89 & 0,62
\end{tabular}



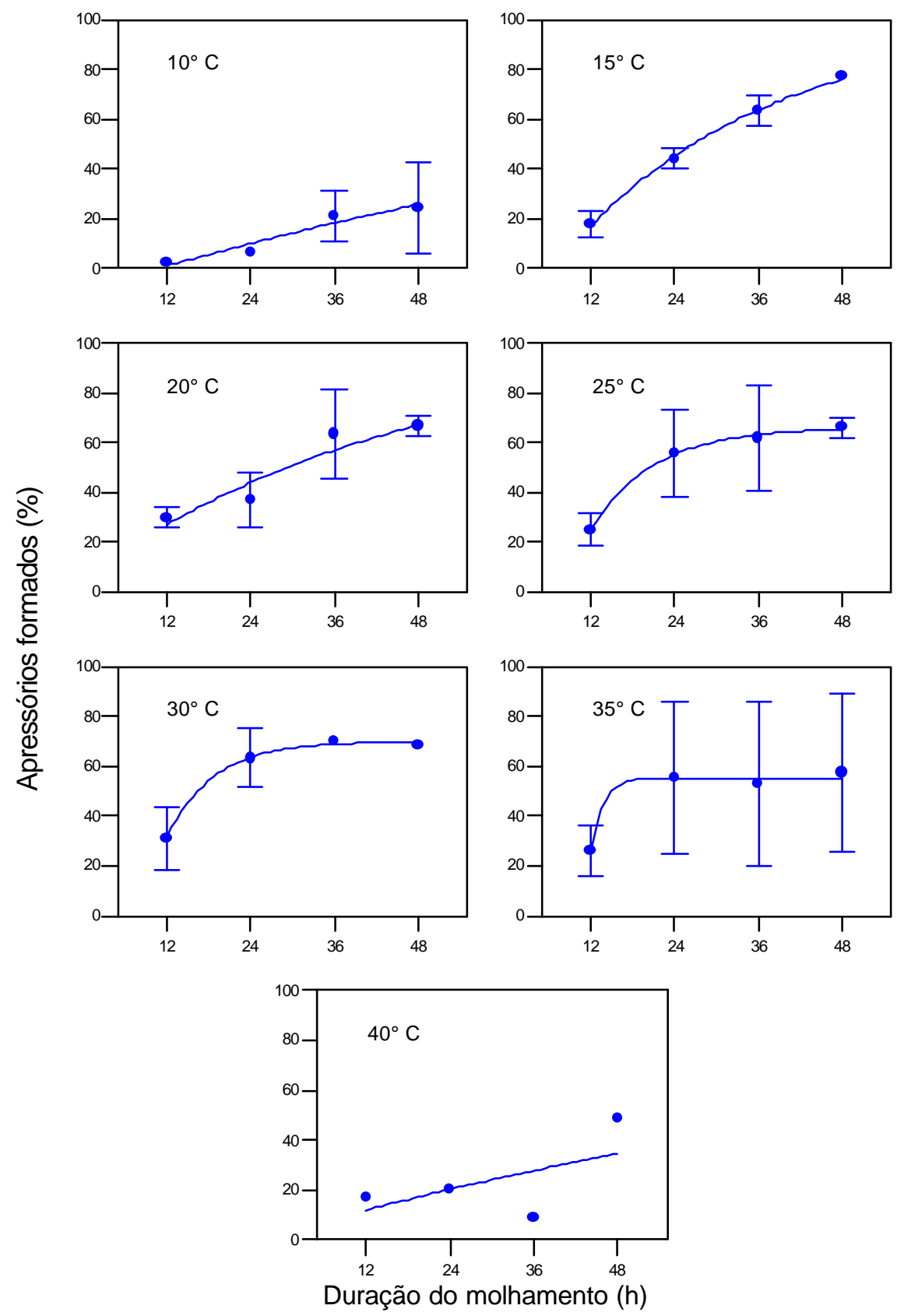

Figura 2 - Porcentagem relativa de apressórios de Guignardia citricarpa (Phyllosticta citricarpa) formados em função de diferentes períodos de molhamento (12, 24, 36 e 48 horas) e temperaturas $\left(10,15,20,25,30,35\right.$ e $\left.40{ }^{\circ} \mathrm{C}\right)$. Pontos representam as médias e barras o erro médio de dois experimentos. A linha representa ajuste obtido com o modelo monomolecular. 
Tabela 2. Coeficientes de determinação $\left(R^{2}\right)$ e parâmetros da função monomolecular, $Y=B_{1}\left(1-B_{2} \exp \left(-B_{3} M\right)\right)$, onde $Y$ é a porcentagem relativa de apressórios formados, $M$ é a duração do molhamento, $B_{1}$ é a estimativa da assíntota máxima, $B_{2}$ é um parâmetro do modelo e $B_{3}$ é a taxa de progresso da formação de apressórios, ajustada para as diferentes temperaturas.

\begin{tabular}{ccccc}
\hline Temperaturas $\left({ }^{\mathbf{0}} \mathbf{C}\right)$ & $\boldsymbol{B}_{1}$ & $\boldsymbol{B}_{\mathbf{2}}$ & $\boldsymbol{B}_{\mathbf{3}}$ & $\boldsymbol{R}^{\mathbf{2}}$ \\
\hline 10 & 100 & 1,09 & 0,008 & 0,94 \\
15 & 100 & 1,25 & 0,034 & 0,99 \\
20 & 100 & 0,95 & 0,022 & 0,90 \\
25 & 66,10 & 2,36 & 0,110 & 0,99 \\
30 & 69,96 & 3,40 & 0,150 & 0,99 \\
35 & 55,38 & 484,58 & 0,570 & 0,98 \\
40 & 100 & 0,97 & 0,008 & 0,35 \\
\hline
\end{tabular}

Em condições controladas, a infecção acontece sob uma grande amplitude de temperaturas, de menos de $10{ }^{\circ} \mathrm{C}$ (normalmente a mais baixa temperatura testada) a $40{ }^{\circ} \mathrm{C}$ ou acima. Registros de temperaturas mínima e máxima para infecção são menos comuns que registros de temperaturas críticas para germinação. Com várias exceções, a temperatura ótima é relatada próxima ou acima de $25{ }^{\circ} \mathrm{C}$. Em alguns casos a temperatura ótima para infecção é semelhante à temperatura ótima para germinação que pode refletir a exigência geral do fungo. Em outros casos a temperatura ótima é diferente, o que pode ser atribuído a uma reação específica do hospedeiro, que sucumbe à infecção sob condições não necessariamente ótimas para germinação do esporo ou penetração (Rotem, 1994). Neste trabalho, não foi possível determinar a temperatura ótima, visto que a formação de apressórios deu-se numa ampla faixa de temperaturas favoráveis (15 a $35{ }^{\circ} \mathrm{C}$ ). Para outros patógenos, como o fungo Magnoporthe grisea, agente causal da brusone do arroz, a germinação de conídios e formação de apressórios ocorre na superfície de folhas de arroz na presença de gotas de água numa grande amplitude de 
temperaturas que variam entre 10 e $33{ }^{\circ} \mathrm{C}$, com ótimo para germinação entre 25 e $28{ }^{\circ} \mathrm{C}$, e para formação de apressórios entre 16 e $25{ }^{\circ} \mathrm{C}$ (Suzuki, 1969).

Sullivan et al. (2002) observaram que plantas de espinafre inoculadas com Albugo occidentalis, agente causal da ferrugem branca, submetidas a temperaturas que variaram de 6 a $28{ }^{\circ} \mathrm{C}$ e períodos de molhamento de 0 (zero) a 84 horas, apresentaram sintomas da doença em todas as temperaturas e a severidade da doença aumentou com a duração do molhamento. Na ausência de molhamento não ocorreu doença. De acordo com Gross a al. (1998), os efeitos da temperatura são mais pronunciados para períodos de duração de molhamento mais longos que períodos mais curtos, indicando que a umidade foliar talvez seja a variável ambiental crítica para infecção, entretanto a temperatura regula a rapidez e o nível de desenvolvimento da doença.

A ausência de temperaturas mínima, máxima e ótima fixas, sugerem que estes estados ou condições sejam relativos em lugar de absolutos, pois o nível destes estados é modificado através de interações segundo a teoria da compensação (Rotem, 1978). Conforme observado neste estudo e em estudos anteriores (Sullivan et. al, 2002; Filajdiè \& Sutton, 1992; Spotts \& Cervantes, 1991; Sutton \& Arauz 1991; Rotem, 1971), as combinações entre temperatura e molhamento é que são determinantes do processo infeccioso, havendo compensações entre temperaturas menos favoráveis e durações de molhamento, assim como entre molhamentos mínimos e temperaturas mais favoráveis. Quando a temperatura foi $10{ }^{\circ} \mathrm{C}$, foram necessários 48 horas de molhamento para que os conídios formassem 24,51\% de apressórios, enquanto que a $25{ }^{\circ} \mathrm{C}$ em 12 horas de molhamento, 25,06\% de conídios já haviam formado apressório.

A importância da umidade na germinação de conídios, também foi observada por Sutton \& Arauz (1991). Eles observaram que poucos conídios de Botryosphaeria dothidea, agente causal da podridão branca em maçã, germinaram ra ausência de água livre e quando os conídios foram submetidos a umidades relativas que variaram de $95 \%$ a 100\%, a germinação só ocorreu após 12 horas, havendo um decréscimo na germinação com a redução da umidade relativa. A germinação de conídios em água lvre foi maior do que quando os mesmos foram secados e molhados novamente ou mantidos a $100 \%$ de umidade relativa. 
O requerimento para um longo período de molhamento pode ser o resultado da necessidade para debilitar tecidos invadidos, por meio de agentes tóxicos ou enzimáticos, e é possível que esta exigência seja mais comum em infecções por espécies patogênicas fracas. Porém, um período de molhamento longo também pode ser requerido para infecção de órgãos resistentes por espécies virulentas (Rotem, 1994).

Sob condições favoráveis de laboratório, ou seja, na presença de umidade, picnídios de Phyllosticta citricarpa são capazes de produzir culturas de esporos viáveis em um curto espaço de tempo. Dessa forma, condições no pomar são satisfatórias para rápida produção e maturação de conídios, pois noites com molhamentos por orvalhos e chuvas leves, também são condições favoráveis para produção de conídios que germinarão facilmente e infectarão frutos jovens (Kiely, 1948).

Segundo Suzuki (1975), mesmo com 100\% de umidade relativa, gotas de água são essenciais para germinação de conídios de Magnoporthe grisea, agente causal da brusone do arroz. A água na superfície de folhas consiste de chuva, orvalho e gotas de gutação. Sob algumas condições climáticas, estas gotas na superfície desaparecem antes da formação dos apressórios. Como resultado, o protoplasma do conídio coagula e morre. Ainda que dentro de uma faixa de temperaturas favoráveis para germinação, a germinação de conídios pode ser aparentemente diminuída por secamento, após os esporos entrarem em contato com gotas de água por aproximadamente $10 \mathrm{~min}$. Esta diminuição na germinação tende a aumentar com o aumento do tempo de contato com gotas de água, ou aumento do tempo de secagem após o molhamento. O período de tempo no qual gotas de água permanecem na superfície da folha é um fator muito importante na epidemia da brusone do arroz, com influências na germinação e formação de apressórios. Uma vez que a germinação dos conídios está intrisicamente relacionada com a disponibilidade de água, é essencial para o estabelecimento de lesões que o processo inteiro que consiste na germinação, na formação de apressórios, e na invasão do patógeno, devam ser completados antes que as gotas de água evaporem.

A superfície de resposta obtida pela multiplicação das funções beta generalizada, gerada para os ensaios de temperatura, e monomolecular, ajustada para os ensaios de 
duração do período de molhamento (Figura 3), apresentou um ajuste satisfatório para os dados observados na estimativa da porcentagem relativa de apressórios formados $\left(R^{2}=\right.$ 0,75). Através da superfície de resposta podemos observar a grande amplitude de temperaturas a partir de oito horas de molhamento, favoráveis à formação de apressórios. A superfície de resposta pôde ser descrita pela função:

$$
Y=(0,15)\left((T-(9,8))^{\wedge}(0,37)\right)\left(((43,34)-T)^{\wedge}(0,73)\right)(((20,42) /(1+(10,36) \exp (-(0.14) M))))
$$

Onde $Y$ é a percentagem relativa de apressórios formados, $T$ é a temperatura em ${ }^{\circ} \mathrm{C}$ e $M$ é a duração do período de molhamento em horas. Por meio dessas funções, a temperatura mínima para a formação de apressórios foi de $9,8{ }^{\circ} \mathrm{C}$ e a máxima foi de $43,3{ }^{\circ} \mathrm{C}$.

Este modelo descreve a influência da temperatura e da duração do molhamento na formação de apressórios de conídios de $G$. citricarpa ( $P$. citricarpa). A relação definida entre formação de apressórios e condições ambientais poderá ser útil em um programa de sistema de alerta da doença, cujo propósito é determinar o momento ideal para pulverizações com fungicidas no campo. 


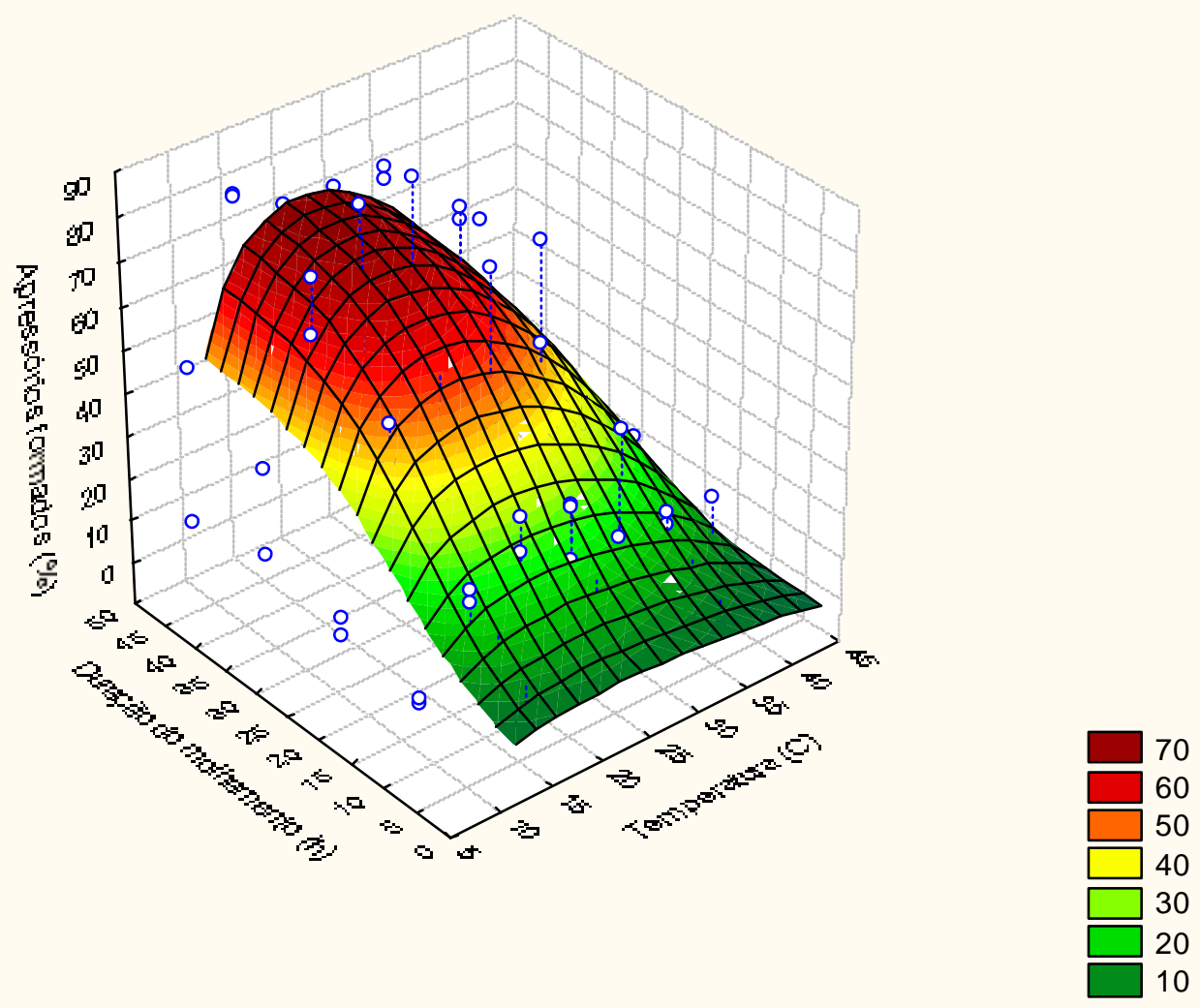

Figura 3 - Superfície de resposta da porcentagem relativa de apressórios formados, em função da temperatura e da duração do período de molhamento, descrita pela função $Y=\left(B_{1}\left(\left(T-B_{2}\right)^{\wedge} B_{3}\right)\left(\left(B_{4}-T\right)^{\wedge} B_{5}\right)\right)\left(\left(B_{6} /\left(1-B_{7} \exp \left(-B_{8} M\right)\right)\right)\right.$, onde $Y$ é a percentagem relativa de apressórios formados, $T$ é a temperatura, $M$ é a duração do período de molhamento e $B_{1}$ a $B_{8}$ são parâmetros do modelo. 


\subsubsection{Observação ao microscópio eletrônico de varredura da germinação e formação de apressórios de conídios de Guignardia citricarpa (Phyllosticta citricarpa) sobre folhas destacadas de limão 'Siciliano' submetidas a diferentes temperaturas e períodos de molhamento}

As amostras observadas em microscopia eletrônica de varredura possibilitaram a aquisição de imagens de conídios germinando e formando apressórios sobre a superfície de folhas de limão 'Siciliano' em todas as combinações de temperatura e molhamento (Figuras 4 e 5), com exceção da amostra submetida a $15{ }^{\circ} \mathrm{C}$ e 24 horas de molhamento, esta foi danificada durante o seu preparo.

Como verificado nas Figuras 4 e 5, os conídios de G. citricarpa (P. citricarpa) apresentam um único tubo germinativo por onde passa todo o conteúdo protoplasmático do esporo para o apressório. A formação de apressórios neste fungo se caracteriza por apresentar variações de tamanho e forma. Quando o tubo germinativo é longo podemos observar que o apressório é menor, havendo uma distinção entre o esporo e o apressório. Contudo existem situações em que não é possível diferenciar o apressório formado do conídio, devido à ausência ou a um encurtamento do tubo germinativo. Estas características também foram encontradas em ascósporos. Embora o processo de germinação e formação do tubo germinativo de ascósporos se assemelhe ao dos conídios, ascósporos podem apresentar até três tubos germinativos (Kiely, 1948).

Para Magnoporthe grisea, apressórios aparentemente são formados mais freqüentemente quando os conídios aderem firmemente à superfície da planta Suzuki (1975). Gotas de chuva carregadas com conídios causam sua adesão junto à planta de arroz. Isto é presumido como sendo uma das razões para a alta taxa de formação de apressórios em dias chuvosos. A relação entre a taxa de precipitação e ambos, freqüência de formação de apressórios e quantidade de doença, foram observadas durante chuvas de menos de $100 \mathrm{~mm} / \mathrm{h}$.

As observações realizadas neste ensaio, confirmam os resultados encontrados sob

condições "in vitro" para as temperaturas de 15,25 e $35{ }^{\circ} \mathrm{C}$ e os períodos de molhamento de 12, 24 e 48 horas. 

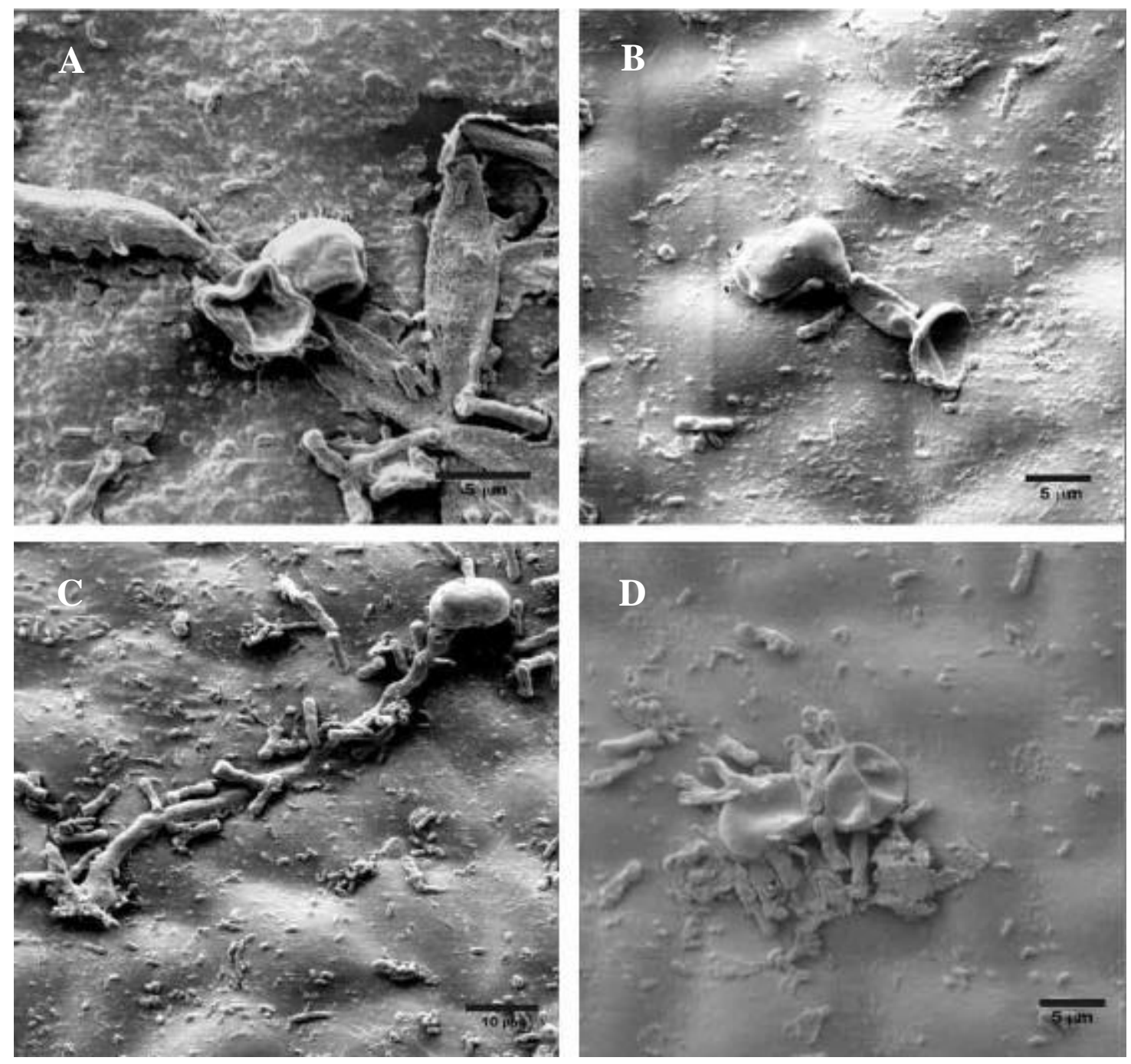

Figura 4 - Elétron-micrografia de varredura da germinação e formação de apressórios de conídios de Guignardia citricarpa (Phillosticta citricarpa) na superfície de folhas de limão 'Siciliano'. Conídios germinados e com apressórios formados a $15{ }^{\circ} \mathrm{C}$ e 12 horas de molhamento (A); $15{ }^{\circ} \mathrm{C}$ e 48 horas de molhamento (B); a $25{ }^{\circ} \mathrm{C}$ e 12 horas de molhamento (C); a $25^{\circ} \mathrm{C}$ e 24 horas de molhamento (D). 

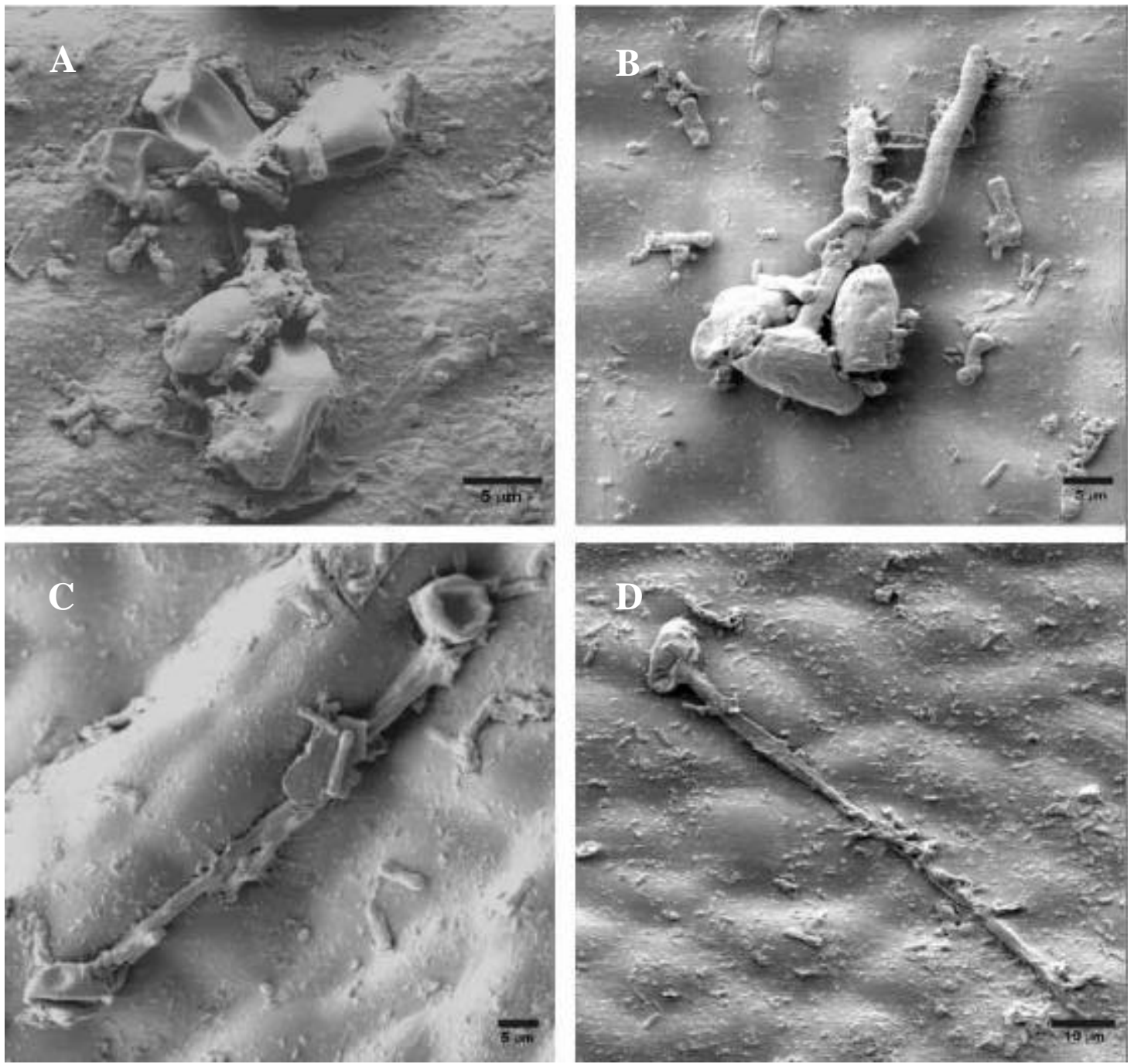

Figura 5 - Elétron-micrografia de varredura da germinação e formação de apressórios de conídios de Guignardia citricarpa (Phillosticta citricarpa) na superfície de folhas de limão 'Siciliano'. Conídios germinados e com apressórios formados a $25{ }^{\circ} \mathrm{C}$ e 48 horas de molhamento (A); a $35{ }^{\circ} \mathrm{C}$ e 12 horas de molhamento (B); a $35{ }^{\circ} \mathrm{C}$ e 24 horas de molhamento (C); a $35{ }^{\circ} \mathrm{C}$ e 48 horas de molhamento (D). 


\subsection{Conclusões}

Os conídios de Guignardia citricarpa (Phyllosticta citricarpa) germinam e formam apressório numa faixa de temperatura que varia de 10 a $40{ }^{\circ} \mathrm{C}$, com uma amplitude de temperaturas favoráveis entre 15 a $35{ }^{\circ} \mathrm{C}$, sendo a umidade, representada nestes ensaios por duração do molhamento, a variável ambiental que mais influencia a formação de apressórios "in vitro".

A germinação e formação de apressório em folhas de limão 'Siciliano', observadas em imagens micrografadas em microscópio eletrônico de varredura, ocorrem em todas as combinações de temperatura e molhamento foliar.

A grande amplitude de condições favoráveis à infecção de conídios de $G$. citricarpa ( $P$. citricarpa) indica que sua ocorrência é muito freqüente e que o melhor manejo da doença deve ser feito por meio de medidas preventivas de controle. 


\section{CONCLUSÕES GERAIS}

A escala diagramática elaborada neste trabalho é recomendada como uma ferramenta de auxílio na estimativa da severidade da mancha preta dos citros causada por Guignardia citricarpa (Phyllosticta citricarpa).

A ampla gama de temperaturas nas quais há formação de apressórios a partir de

conídios indica que a infecção ocorre em qualquer época do ano, sendo mais influenciada pela disponibilidade de inóculo do que pelo clima. 


\section{REFERÊNCIAS BIBLIOGRÁFICAS}

AGUILAR-VILDOSO, C.I.; AZEVEDO, J.L. Infecção de frutos maduros de citros por picnidiósporos de Guignardia citricarpa. Fitopatologia Brasileira. v.26, p.327, 2001. Suplemento. /Apresentado ao 34., Congresso Brasileiro de Fitopatologia, São Pedro, 2001 - Resumo/

AGUILAR-VILDOSO, C.I. (Coordenador). Manual técnico de procedimentos da mancha preta dos citros. Brasília: MAPA/DAS/DDIV, 2002. 72p.

ALCOBA, N.J.; VIGIANI, A.R.; BEJARANO, N.V.; SLVAREZ, S.E.; SERRANO, M.A.; BONILLO, M.C. Mancha negra de los citros: epidemiología y control. San Salvador de Jujuy: Ediciones Universidad Nacional de Jujuy, 2000, 56p.

AMORIM, L.; BERGAMIN FILHO, A.; PALAZZO, D.; BASSANEZI, R.B.; GODOY, C.V.; TORRES, G.A.M. Clorose variegada dos citros: uma escala diagramática para avaliação da severidade da doença. Fitopatologia Brasileira,v.18, n.2, p.174-180, 1993.

AMORIM, L. Avaliação de doenças. In: BERGAMIN FILHO, A.; KIMATI, H; AMORIM, L (Ed.). Manual de fitopatologia: princípios e conceitos. 3. ed. São Paulo: Agronômica Ceres, 1995. v.1, p.647-671. 
BALDASSARI, R.B. Influência de frutos sintomáticos de uma safra na incidência da Guignardia citricarpa na safra subseqüente e período de suscetibilidade de frutos de laranjeiras 'Natal' e 'Valência'. Jaboticabal, 2001a, 60p. Dissertação (Mestrado) Universidade Estadual Paulista, Faculdade de Ciências Agrárias e Veterinárias, Campus de Jaboticabal. "Júlio de Mesquita Filho".

BALDASSARI, R.B.; GOES, A.; SANTOS, J.M.; TIMOSSI, A.J. Microscopia eletrônica de varredura de isolados de Guignardia citricarpa obtidos de plantas cítricas. Summa Phytopathologica, v.27, n.1, p.88-92, 2001 b.

BERGAMIN FILHO, A. Curvas de progresso da doença. In: BERGAMIN FILHO, A.; KIMATI, H; AMORIM, L (Ed.). Manual de fitopatologia: princípios e conceitos. 3. ed. São Paulo: Agronômica Ceres, 1995. v.1, p.602-625.

BERGAMIN FILHO, A.; AMORIM, L. Doenças de plantas tropicais: epidemiologia e controle econômico. São Paulo: Agronômica Ceres, 1996. 299p.

BERGER, R.D. Measuring disease intensity. In: TENG, P.S.; KRUPA, S.V. (Ed.). Crop loss assessment. Saint Paul: University of Minnesota, 1980. p.28-31.

BOTEON, M. Cadeia agroindustrial de citros. Centro de Estudos Avançados em Economia Aplicada (CEPEA/ESALQ/USP). http://cepea.esalq.usp.br 14p. (25 out.2002)

BRODRICK, H.T.; RABIE, C.J. Light and temperature effects on symptom development and sporulation of Guignardia citricarpa Kiely, on Citrus sinensis (Linn) Osbeck. Phytophylactica. v.2, p.157-164, 1970.

COLHOUN, J. Effects of environmental factors on plant disease. Annual Review of Phytopathology, v.11, p.343-364, 1973. 
DÍAZ, C.G.; BASSANEZI, R.B.; BERGAMIN FILHO, A. Desenvolvimento e validação de uma escala diagramática para Xanthomonas axonopodis pv. phaseoli em feijoeiro. Summa Phytopathologica, v.27, n.1, p.35-39, 2001.

DOIDGE, E.M. Some diseases of citrus prevalent in South Africa. South African Journal Science. v.26, p.320-325, 1929.

EMMETT, R.W.; PARBERY, D.G. Apressoria. Annual Review of Phytopathology, v.13, p.147-167, 1975.

FEICHTENBERGER, E. Mancha-preta dos citros no Estado de São Paulo. Laranja, v.17, p.93-108, 1996.

FEICHTENBERGER, E.; MÜLLER, G.W.; GUIRADO, N. Doenças dos citros (Citrus spp.). In: KIMATI, H.; AMORIM, L.; BERGAMIN FILHO, A.; CAMARGO, L.E.A.; REZENDE, J.A.M. (Ed.). Manual de fitopatologia: doenças da plantas cultivadas. São Paulo: Ceres, 1997. v. 2, p.261-296.

FILAJDIÈ, N.; SUTTON, T.B. Influence of temperature and wetness duration on infection of apple leaves and virulence of different isolates of Alternaria mali. Phytopathology, v.82, n.11, p.1279-1283, 1992.

FNP CONSULTORIA \& COMÉRCIO. Agrianual 2001: Anuário de agricultura brasileira. São Paulo, 2001. p.275-313.

FNP CONSULTORIA \& COMÉRCIO. Agrianual 2002: Anuário de agricultura brasileira. São Paulo, 2002. p.285-332. 
FUNDECITRUS. Manual técnico sobre pinta preta. Araraquara: Fundo Paulista de Defesa da Citricultura, 1998. 10p. (Boletim Técnico).

GLIENKE de BLANCO, C. Guignardia citricarpa Kiely: análise genética, cariotípica e interação com o hospedeiro. Piracicaba, 1999. 200p. Tese (Doutorado) - Escola Superior de Agricultura “Luiz de Queiroz”, Universidade de São Paulo.

GODOY, C.V.; CARNEIRO, S.M.T.P.G.; IAMAUTI, M.T.; PRIA, M.D.; AMORIM, L.; BERGER, R.D.; BERGAMIN FILHO, A. Diagrammatic scales for bean diseases: development and validation. Zeitschrift für Pflanzenkrankheiten und Pflanzenschutz, v.104, n.4, p.336-345, 1997.

GOES, A. de; FEICHTENBERGER, E. Ocorrência da mancha preta causada por Phyllosticta citricarpa (McAlp) Van der Aa (Guignardia citricarpa Kiely) em pomares cítricos do Estado de São Paulo. Fitopatologia Brasileira, v.18, p.138, 1993. Suplemento. /Apresentado ao 26., Congresso Brasileiro de Fitopatologia, Aracajú, 1993 - Resumo/

GOES, A. de; Controle da mancha-preta dos frutos cítricos. Laranja, v.19, p.305-320, 1998.

GOES, A. de; ANDRADE, A.G.; MORETTO, K.C.K. Efeito de diferentes tipos de óleos na mistura de benomil + mancozeb no controle de Guignardia citricarpa, agente causal da mancha preta dos frutos cítricos. Summa Phytopathologica, v.26, p.233-236, 2000.

GOES, A. Efeito da combinação de fungicidas sistêmicos e protetores no controle da mancha preta dos frutos cítricos causada por Guignardia citricarpa. Summa Phytopathologica, v.28, p.9-13, 2002. 
GROSS, M.K.; SANTINI, J.B.; TIKHONOVA, I.; LATIN, R. The influence of temperature and leaf wetness duration on infection of perennial ryegrass by Rhizoctonia solani. Plant Disease, v.82, n.9, p.1012-1016, 1998.

HAU, B.; KRANZ, J. Mathematics and statistics for analysis in epidemiology. In: KRANZ, J. (Ed.). Epidemics of plant diseases: mathematical analysis and modeling. Berlin: Springer-Verlag, 1990. p.12-52.

HORSFALL, J.G.; BARRAT, R.W. An improved grading system for measuring plant disease. Phytopathology, v.35, p.655, 1945.

HORSFALL, J.G.; COWLING, E.B. Patometry: the measurement of plant disease. In: HORSFALL, J.G.; COWLING, E.B (Ed.). Plant disease: an advanced treatise. How disease develops in populations. New York: Academic Press, 1978, v.2, p.119-136.

HOTO, F.V.; AGUILAR-VILDOSO, C.I.; ROSSI, M.L.; NOGUEIRA, N. L. Acompanhamento do processo ontogênico de pcnídios de Guignardia citricarpa. Fitopatologia Brasileira, v. 26, p.430, 2001. Suplemento. /Apresentado ao 34., Congresso Brasileiro de Fitopatologia, São Pedro, 2001 - Resumo/

HUBER, L.; GILLESPIE, T.J. Modeling leaf wetness in relation to plant disease epidemiology. Annual Review of Phytopathology, v.30, p.553-577, 1992.

JAMES, W.C. An illustrated series assessment keys of plant diseases. Their preparation and usage. Canadian Plant Disease Survey, v.5, n.2, p.39-65, 1971.

KIELY, T.B. Preliminary studies on Guignardia citricarpa spp.: the ascigenous stage of Phoma citricarpa McAlp. and its relation to black spot of citrus. Proceedings of the Linnean Society of New South Walesn. v.73, p.249-292, 1948. 
KIELY, T.B. Black spot of citrus in New South Wales coastal orchards. The Agricultural Gazette. v.1, p.17-20, 1949.

KITAJIMA, E.W.; LEITE, B. Curso introdutório de microscopia eletrônica de varredura. Piracicaba: ESALQ, NAP, MEPA - USP), 1999. 45p.

KLOTZ, L.J. Fungal, bacterial, and nonparasitic diseases and injuries originating in the seebed, nursey, and orchard. In: REUTHER, W.; CALAVAN, E.C.; CARMAN, G.E. (Ed.) The Citrus Industry. Riverside, University of California, 1978. p.1-66.

KOTZÉ, J.M. Studies on the black spot disease of citrus caused by Guignardia citricarpa Kiely, with particular reference to its epiphytology and control at Letaba. Pretoria, 1963. 143p. Thesis (Doctor). University of Pretoria.

KOTZÉ, J.M. Epidemiology and control of citrus black spot in South Africa. Plant Disease, v.65, n.12, p.945-950, 1981.

KOTZÉ, J.M. Black spot. In: WHITESIDE, J.O.; GARNSEY, S.M.; TIMMER, L.W. (Ed.). Compendium of Citrus Diseases. St. Paul, APS Press, 1988, p.10-12.

KOTZÉ, J.M. History and epidemiology of citrus black spot in South Africa. Proceedings of International Society of Citriculture, v.2, p.1296-1299, 1996

KRANZ, J. A study in maximum severity in plant diseases. In: Traveaux dédiés à Georges Viennot-Bourgin. Paris: Société Française de Phytopathologie, 1977. p.167-173. 
LEITE, R.M.V.B.C.; AMORIM, L. Elaboração e validação de escala diagramática para mancha de Alternaria em girassol. Summa Phytopathologica, v.28, n.1, p.1-6, 2002.

MADDEN, L.V.; NUTTER JUNIOR., F.W. Modeling crop losses at the field. Canadian Journal of Plant Pathology, v.17, p.124-137, 1995.

McONIE, K.C. Source of inoculum of Guignardia citricarpa, the citrus black spot pathogen. Phytopathology, v.54, p.64-67, 1964a.

McONIE, K.C. Orchard development and discharge of ascospores of Guignardia citricarpa and the onset of infection in relation to the control of citrus black spot. Phytopathology, v.54, p.1448-1453, 1964b.

McONIE, K.C. The latent occurrence in citrus and other hosts of Guignardia easily confused with Guignardia citricarpa, the citrus black spot pathogens. Phytopathology, v.54, p.40-3, 1964c.

McONIE, K.C. Source of infection for black spot of citrus. The South African Citrus Journal, June, p.5-9, 1965.

McONIE, K.C. Germination and infection of citrus by ascospores of Guignardia citricarpa in relation to control of black spot. Phytopathology, v.57, p.743-746, 1967.

MENDGEN, K.; HAHN, M.; DEISING, H. Morphogenesis and mechanisms of penetration by plant pathogenic fungi. Annual Review of Phytopathology. v.34, p.367 -386, 1996. 
MICHEREFF, S.J.; PEDROSA, R.A.; NORONHA, M.A.; MARTINS, R.B.; SILVA, F.V. Escala diagramática e tamanho de amostras para avaliação da severidade da mancha parda da mandioca (Cercosporidium henningsii). Agrotrópica, v.10, n.3, p.143-148, 1998.

MICHEREFF, S.J.; MAFFIA, L.A.; NORONHA, M.A. Escala diagramática para avaliação da severidade da queima das folhas do inhame. Fitopatologia Brasileira, v.25, n.4, p.612-619, 2000.

NAIR, K.R.S.; ELLINGBOE, A.H. Germination of conidia of Erysiphe graminis f.sp. tritici. Phytopathology, v.55, p.365-368, 1965.

NILSSON, H.E. Remote sensing and image analysis in plant pathology. Canadian Journal of Plant Pathology, v.17, p.154-166, 1995.

NUTTER JUNIOR, F.W.; WORAWITLIKIT, O. Disease.Pro: A computer program for evaluating and improving a person ability to assess disease proportion. Phytopathology, v.79, n.10, p.1135, 1989. (Abstract).

NUTTER JUNIOR, F.W.; TENG, P.S.; SHOKES, F.M. Disease assessment terms and concepts. Plant Disease, v.75, n.11, p.1187-1188, 1991.

NUTTER JUNIOR, F.W.; GLEASON, M.L.; JENCO, J.H.; CHRISTIANS, N.C. Assessing the accuracy, intra-rater repeatability, and inter-rater reliability of disease assessment systems. Phytopathology, v.83, n.8, p.806-812, 1993.

NUTTER JUNIOR, F.W.; SCHULTZ, P.M. Improving the accuracy and precision if disease assessments: selection of methods and use of computer-aided training programs. Canadian Journal of Plant Pathology, v.17, p.174-184, 1995. 
O'BRIEN, R.D.; VAN BRUGGEN, A.H.C. Accuracy, precision, and correlation to yield loss of disease severity scales for corky root of etucce. Phytopathology, v.82, n.1, p.91-96, 1992.

PARKER, S.R.; SHAW, M.W.; ROYLE, D.J. The reliability of visual estimates of disease severity on cereal leaves. Plant Pathology, v.43, n.6, p.856-865, 1995.

ROBBS, C.F.; PIMENTEL, J.P.; RIBEIRO, R.L. A mancha preta dos citros causada por Phoma citricarpa. Fitopatologia Brasileira, v.15, n.3, p.455, 1980. Suplemento. /Apresentado ao 13., Congresso Brasileiro de Fitopatologia, Rio de Janeiro, 1980 Resumo/

ROBBS, C.F.; PIMENTEL, J.P.; RIBEIRO, R.L. A mancha preta dos citros: identificação da forma perfeita Guignardia citricarpa no Estado do Rio de Janeiro. Fitopatologia Brasileira, v.10, n.2, p.248, 1985. Suplemento. /Apresentado ao 18., Congresso Brasileiro de Fitopatologia, Fortaleza, 1985 - Resumo/

ROBBS, C.F. A mancha preta dos frutos cítricos (Phyllosticta citricarpa): ameaça à citricultura paulista. Laranja, v.11, p.87-95,1990.

ROBBS, C.F.; BITTENCOURT, A.M. A mancha preta dos frutos: um dos fatores limitantes à produção citrícola do Estado do Rio de Janeiro. Guaratiba, EMBRAPA/CTAt, 1995, 5p. (Comunicado Técnico, 19).

ROTEM, J. Relativity of limiting and optimum inoculum loads, wetting durations, and temperatures for infection by Phytophthora infestans. Phytopathology, v.61, p.275$278,1971$. 
ROTEM, J. Climatic and weather influences on epidemics. In: HORSFALL, J.G.; COWLING, E.B. (Ed.). Plant Disease: an advanced treatise. Academic Press, New York, v.2, p.317-337, 1978.

ROTEM, J. Infection. In: ROTEM, J. The genus Alternaria: biology, epidemiology and pathogenicity. APS Press, p.77-94, 1994.

SCHINOR, E.H.; FEICTHTENBERGER, E.; GOES, A.; SPOSITO, M.B.; RUBIM, C.; AGUILAR-VILDOSO, C.I. Lesões encharcadas associadas à mancha preta dos citros (Guignardia citricarpa). Fitopatologia Brasileira, Brasília, v.26, p.337, 2001a. Suplemento. /Apresentado ao 34., Congresso Brasileiro de Fitopatologia, São Pedro, 2001 - Resumo/

SCHINOR, E.H. Resistência de clones de laranjeira 'pêra' e variedades afins à Mancha Preta dos Citros. 2001b. 90p. Dissertação (Mestrado) - Escola Superior de Agricultura “Luiz de Queiroz”, Universidade de São Paulo.

SCHUTTE, G.C.; BEETON, K.V; KOTZÉ, J.M. Rind stippling on Valencia oranges by copper fungicides used for control of citrus black spot in South Africa. Plant Disease, v.81, p.851-854, 1997.

SMITH, J.H. A study of the effect of various disease control programs on spore releases of the citrus black spot pathogen Guignardia citricarpa Kiely. Proceedings of International Society of Citriculture, v.1, p.351-352, 1996. 
SPÓSITO, M.B.; BASSANEZI, R.B.; FARIAS, P.R.; LOURENÇO, S.A.; LARANJEIRA, F.F.; AMORIM, L.; BERGAMIN FILHO, A. Distribuição espacial da mancha preta dos citros em pomar de laranjeira "Natal". Fitopatologia Brasileira, v.26, p.409, 2001. Suplemento. /Apresentado ao 34., Congresso Brasileiro de Fitopatologia, São Pedro, 2001 - Resumo/

SPOTTS, R.A.; CERVANTES, L.A. Effect of temperature and wetness on infection if pear by Venturia pirina and the relationship between preharvest inoculation and storage scab. Plant Disease, v.75, n.12, p.1204-1207, 1991.

SULLIVAN, M.J.; DAMICONE, J.P.; PAYTON, M.E. The effects of temperatures and wetness period on the development of spinach white rust. Plant Disease, v.86, n.7, p.753-758, 2002.

SUTTON, B.C.; WATERSON, J.M. Guignardia citricarpa. Descriptions of pathogenic fungi and bacteria. Guignardia citricarpa. Surrey, England, Kew: Commonwealth Mycological Institute, 1966. n.85, 2p.

SUTTON, T.B.; ARAUZ. L.F. Influence of temperature and moisture on germination of ascospores and conidia of Botryosphaeria dothidea. Plant Disease, v.75, n.11, p.1146-1149, 1991.

SUZUKI, H. Temperature related to the spore germination and appressorium formation of rice blast fungus. Proc. Assoc. Plant Protection, v.17, p.6-9, 1969.

SUZUKI, H. Meteorological factors in the epidemiology of rice blast. Annual Review of Phytopathology. v.13, p.239 -256, 1975. 
TIMOSSI, J.A. Influência de fatores físicos no desenvolvimento do teleomorfo de Guignardia citricarpa, agente causal da mancha negra dos frutos cítricos Jaboticabal, 2000, 58p. (Monografia) - Universidade Estadual Paulista, Faculdade de Ciências Agrárias e Veterinárias, Campus de Jaboticabal, “Júlio de Mesquita Filho”.

TOMERLIN, J.R.; HOWELL, T.A. Distrain: a computer program for training people to estimate disease severity on cereal leaves. Plant Disease, v.72, n.4, p.455-459, 1988.

WEBER, G.E.; JORG, E. Errors in disease assessment a survey. Phytopathology, v.81, n.10, p.1238, 1991. 